\title{
Extreme events in the sedimentary record of maar Lake Pavin: implications for natural hazards assessment in the French Massif Central
}

Léo CHASSIOT a, Emmanuel CHAPRON ${ }^{\text {a,b }}$, Christian DI GIOVANNI a, Patrick ALBERIC a, Patrick LAJEUNESSE ${ }^{c}$, Anne-Catherine LEHOURS ${ }^{d}$, Michel MEYBECK ${ }^{\mathrm{e}}$

a Institut des Sciences de la Terre d'Orléans (ISTO), UMR 7327, CNRS, Université d’Orléans, BRGM, 1A, rue de la Férollerie, 45071 Orléans Cedex 2, France.

${ }^{\mathrm{b}}$ Géographie de I'Environnement (GEODE), UMR 5602 CNRS, Université Toulouse 2 Jean Jaurès, Allée A. Machado, 31058 Toulouse Cedex, France.

c Centre d'Etudes Nordiques (CEN) \& Département de Géographie, Université Laval, Pavillon Abitibi-Price, 2405, rue de la Terrasse, Québec G1V 0A6, Canada.

' Laboratoire Microorganismes, Génome et Environnement (LMGE), UMR 6023, CNRS, Univ. Blaise Pascal, 24 avenue des Landais, Aubière, 63177, France.

${ }^{\text {e }}$ Milieux Environnementaux, Transferts et Interactions dans les hydrosystèmes et les Sols (METIS), UMR 7619, CNRS, Univ. Pierre et Marie Curie, 4 place Jussieu 75252 Paris cedex 05, France. 


\section{ABSTRACT}

A set of sedimentary cores, high resolution swath bathymetry and subbottom profiler data provides new insights on sedimentary processes in meromictic maar Lake Pavin, France. Three sedimentary environments (i.e., littoral, plateau and basin) have been identified in the lake from sediment composition using bulk organic geochemistry and the analysis of hydroacoustic images. Various forms of rapidly deposited layers (RDLs) have been identified and radiocarbon dated. An up to date stratigraphy of sedimentary events matching coeval RDLs across the lake is presented and illustrates a wide range of natural hazards linked to Lake Pavin during the last 2,000 years. In AD 600, a sudden lake outburst triggered a slump deposit along with a $9 \mathrm{~m}$ lake-level drop that drove shifts in sedimentary organic matter composition. Outside the lake, outburst flood deposits have been described downstream and provide sedimentary evidence for this event. The lake-level drop also favored the generation of gravity reworking phenomena, as shown by (1) a regional earthquake-triggered large slope failure on the plateau connected to a mass-wasting deposit in the basin dated to $A D$ 1300 , and (2) a succession of turbidites in AD 1825 and $A D 1860$ contemporaneous to two historic earthquakes, suggesting that this lake is sensitive to earthquakes with a minimum epicentral intensity of V. Finally, past observations of lake water color changes in AD 1783 and $A D$ 1936, similar to reports in other meromictic lakes, match iron-rich deposits identified in maar lake sediments and suggest that Lake Pavin could have undergone limnic eruptions. 


\section{INTRODUCTION}

Volcanogenic lakes represent a high diversity of inland surface waters. Among them, maar lakes (or crater lakes), resulting from crater filling by meteoric and ground waters after a phreato-magmatic eruption, constitute peculiar lacustrine environments where a variety of natural hazards can occur, such as phreato-magmatic eruptions, lahars, limnic gas burst (or limnic eruption), acid gas attack and water contamination after seepage of acidic lake waters (Caracausi et al., 2009, Rouwet et al., 2014, Tassi and Rouwet, 2014). Hydraulic-related hazards are also common in many volcanic and intra-caldera lakes around the world and could represent substantial hazards to local residents (Manville, 2010, 2015).

Limnic gas burst occurred in lakes Monoun and Nyos in Cameroon in 1984 and 1986, where they caused 37 and 1,746 casualties, respectively. Thirty years later, the scientific community now supports the theory of a sudden release of gas stored in the hypolimnion during lake overturn to generate a carbon dioxide eruption (Cotel, 1999, Mott and Woods, 2010). Such events happen when lake water stratification is disturbed. They can be triggered by subaquatic or subaerial landslide into the deep waters (Sigurdsson et al., 1987, Chapron et al., 2010), seasonal mixing (Kling et al., 1987), supersaturation of dissolved gases (Evans et al., 1993, 1994) and/or a combination of these factors (Rouwet et al., 2014).

Shortly after the Nyos eruption, questions were raised in regards to the potential hazard for a similar event in Lake Pavin, an analogous maar lake in France. Many studies have documented the physical and chemical properties of its water column and report the presence of a dense body of permanent anoxic, sulfidic and iron-rich waters (Viollier et al., 1995, Assayag et al., 2008) with an accumulation of dissolved gases of both volcanic and biogenic origin (Aeschbach-Hertig et al., 1999, Olive and Boulègue, 2004). Hazard for a gas burst today is existent but not elevated under normal conditions (Camus et al., 1993).

Despite this limited hazards today, sedimentary events with the potential to have triggered catastrophic lake overturns have occurred in the past, as evidenced by two large mass- 
wasting deposits (MWD) documented at different sites in Lake Pavin (Chapron et al., 2010, 2012). These results highlight the need to evaluate the impact of past extreme events within the sedimentary record in order to better assess the natural hazards in this specific environment. Moreover, sedimentary investigations are sparse for this volcanic area, where little is known about the potential hazards. For instance, previous studies in Lake Pavin described its sedimentation, essentially made of annually laminated diatomite and documented the record of climate change over the last 700 years using pollen and diatom assemblages (Stebich et al., 2005), geochemical data (Schettler et al., 2007) or the evolution of carbon cycling since the formation of the lake (Albéric et al., 2013).

The present paper proposes a synthesis of previous limnogeological studies performed in Lake Pavin and presents a new stratigraphy of sedimentary events related to abrupt environmental changes. This work is supported by hydroacoustic mapping along with multiproxy analyses and radiocarbon dates performed on a new long piston core (PAV12) collected in the deepest part of the lake, complementary to previous sedimentary cores detailed in Chapron et al. $(2010,2012)$. Identification of rapidly deposited layers (RDLs) lead to the establishment of a novel event stratigraphy of past extreme events and for further assessment of past and present natural hazards in such volcanic environments.

\section{GENERAL SETTING}

\subsection{Geological setting and historic regional seismicity}

Lake Pavin (N45²9'45"; E253'18"; 1197 m above sea level (a.s.l.)) is located in the volcanic area of the Mont Dore massif, in the French Massif Central (Fig. 1A). Fig. The Mont Dore volcanic province is flanked east and west by two major but barely active faults (Houiller and Limagne faults). Consequently, the seismic hazard is today considered as moderate compared to the Alps and the Pyrenees. Several earthquakes with epicenter MSK intensities ranging from IV to VIII have been, however, reported for the last 500 years according to SISFRANCE and AHEAD databases (Fig. 1B; Lambert et al., 1997, Stucchi et al., 2013). In 
chronological order, the largest seismic events have been felt near the city of ClermontFerrand during the late $\mathrm{XV}^{\text {th }}$ century in $\mathrm{AD} 1477$, with a moment magnitude $(\mathrm{Mw})$ of $5.8 \pm 0.5$ and an epicenter intensity (lo) of VII, and AD 1490 with a Mw of $6.1 \pm 0.3$ and an lo of VIII (Baumont and Scotti, 2011). Two moderate seismic events stroke the southern part of the Limagne fault in $A D 1833(\mathrm{lo}=\mathrm{VI}$ and $\mathrm{Mw}=5 \pm 0.3)$ and $\mathrm{AD} 1892(\mathrm{lo}=\mathrm{Vl} 1 / 2$ and $\mathrm{Mw}=5.5 \pm 0.3)$. Finally, limited earthquakes have also been perceived in AD $1844(\mathrm{lo}=\mathrm{V} 1 / 2$ and unknown $\mathrm{Mw})$, $\mathrm{AD1863}(\mathrm{lo}=\mathrm{V}$ and $\mathrm{Mw}=3.4 \pm 0.6)$ and $\mathrm{AD} 1921$ (lo=IV and unknown $\mathrm{Mw}$ ), all clustered beneath the Mont Dore massif.

\subsection{Lake Pavin}

Lake Pavin lies inside a crater formed ca. 7,000 years ago, when an ascending magma met surface waters to create a phreato-magmatic explosion, along with ejection of pumices, volcanic bombs and other basaltic fragments (Bourdier, 1980). The cavity was then fed by meteoric and groundwater to create the present small maar lake Pavin $\left(0.44 \mathrm{~km}^{2}\right)$. Almost circular in shape with a diameter of $750 \mathrm{~m}$, its maximum water depth reaches $92 \mathrm{~m}$ at the center part (Fig. 1B). A subaquatic plateau documented on the northern side reaches $55 \mathrm{~m}$ water depth (Chapron et al., 2010). The topographic catchment area $\left(0.36 \mathrm{~km}^{2}\right)$ encompasses the crater rim made of Pavin volcanic material whose edges culminate at $1,253 \mathrm{~m}$ a.s.l, with steep inner slopes $\left(>45^{\circ}\right)$. It also includes in the southern part the summit of the Puy de Montchal volcano at 1407 m a.s.l., a former structure cut by the Pavin crater during the phreato-magmatic explosion (Fig. 1B).

Due to the higher elevation of the crater rim, the lake waters are protected from winds, inhibiting seasonal mixing. Thus, two water bodies can be distinguished in Lake Pavin. The first corresponding to the upper $60 \mathrm{~m}$ (i.e. mixolimnion), is oxygenated and frequently covered by ice during winter months. The second represents the deep and permanently anoxic and iron-rich waters below $60 \mathrm{~m}$ depth (i.e., monimolimnion), where gases of both volcanic and biogenic origin typical of lake meromixis accumulate (Aeschbach-Hertig et al., 1999, Olive and Boulègue, 2004). 
Several springs occur along the rim in the terrestrial crater. Along with seasonal snowmelt, they are considered as the main suppliers for inflows (Fig. 1B). At about $45 \mathrm{~m}$ depth, sublacustrine springs have also been inferred to balance the lake water budget (Assayag et al., 2008) and maintain the current meromixis (Bonhomme et al., 2011). Accordingly, the hydrologic drainage basin differs from the topographic catchment area and still remains poorly defined. Water escapes from the lake by surface and subaquatic outlets (Chapron et al., 2010), both located on the northern side, where a spillway flows from a deep crater incision downstream to the couze Pavin, a tributary of the Allier River in the drainage basin of the Loire River (Fig. 1B).

\section{METHODS}

\subsection{Hydroacoustic mapping and coring operations}

During a spring campaign in 2008, lake floor morphology was investigated using a Reson Seabat 8101 multibeam echosounder on a vessel equipped with a differential GPS to provide detailed images and three dimensional views of submerged topography (Fig. 2A). This data was used to generate a high-resolution $(50 \mathrm{~cm} \times 50 \mathrm{~cm})$ digital elevation model (DEM) and a slope map with ArcGIS software (Fig. 2B). In addition, and to illustrate the basin fill geometries, a high-resolution acoustic stratigraphic surveys was carried out in 2009 using a $12 \mathrm{kHz}$ Knudsen 320 BP subbottom profiler with a conventional GPS (Fig. 3 and 4). Combination of these two hydroacoustic mapping techniques allowed us to well define the sedimentary sequence above the bedrock, except in the deep basin where gas-rich sediment prevents acoustic signal penetration. Sediment thickness and volume calculations have been made from the seismic dataset using The Kingdom Suite software (HIS) and considering a Pwave velocity of $1500 \mathrm{~m} . \mathrm{s}^{-1}$ in lake sediments.

Coring campaigns have been conducted during summers 2008, 2009, 2010 and 2012. Two long piston cores have been collected using an UWITEC coring device (PAV08 on the plateau and PAV12 on the central basin, Fig. 1 and 5). Additionally, three short gravity cores 
have been sampled along the slopes on a North-South transect from the lake shore to the deep central basin ((PAV09-B1, PAV10-E and PAV09-C5, Fig. 1 and 5).

\subsection{Sediment analyses}

New analyses have been carried out to complement previous investigations conducted on cores PAV08 (Chapron et al., 2010) and PAV09-B1, PAV09-C5 and PAV10-E (Chapron et al., 2012). Sections from core PAV08 were photographed following the method described in Chapron et al., 2010. For the entire dataset, hand-held measurements were performed each half centimeter with a Minolta CM-700d for sediment diffuse spectral reflectance (DSR). Combined with visual descriptions, this data set allowed us to characterize sediment composition (Debret et al., 2011 and references therein). Magnetic Susceptibility (MS) measurements were carried out with the same resolution using a Bartington MS2E point sensor. Finally, bulk sediment was sampled to estimate organic carbon content by Rock-Eval (RE) pyrolysis (Talbot and Livingstone, 1989, Meyers and Lallier-Vergès, 1999, Ariztegui et al., 2001, Simonneau et al., 2014). By progressive heating, this method quantifies the amount of hydrocarbon and carbon dioxide contents in the sediment (Behar et al., 2001). Hydrogen Index ( $\mathrm{HI}$, expressed in mg.HC.g $\left.{ }^{-1} \mathrm{TOC}\right)$ and Oxygen Index (OI, expressed in mg.CO2. $\mathrm{g}^{-1} \mathrm{TOC}$ ) are two parameters derived from pyrolysis results and related to the origin of organic matter. This multi-proxy approach is relevant for describing a wide range of lacustrine sedimentary units and distinguishing background sedimentation from rapidly deposited layers (named hereafter RDLs).

\subsection{Dating methods}

Past studies have underlined the complex evolution of carbon cycling in Lake Pavin during the last 7000 years (Albéric et al., 2013). Comparison between radiocarbon ages on bulk sediment and leaf debris provides an offset of ${ }^{14} \mathrm{C}$ representing a contemporary reservoir age of approximately 2,500 years. Dating sedimentary sequence and sedimentary events with bulk sediment is therefore excluded, except to discuss this specific carbon cycling aspect. 
Thus, organic macroremains have been used for AMS radiocarbon measures (Tab. 1). After removing RDLs, age-depth models have then been calculated with CLAM software (Blaauw, 2010) by using the IntCal13 calibration curve (Reimer et al., 2013). For cores retrieved in the central basin, age-depth models have been improved with former calendar age resulting from varve counting performed on cores collected in 1999 and 2001 near the location of cores PAV12 and PAV09-B1 (Stebich et al., 2005, Schettler et al., 2007).

\section{RESULTS AND INTERPRETATIONS}

\subsection{Morphology and sedimentary environments}

Lake Pavin is an almost circular and bowl-shaped basin with steep slopes, a common feature of lakes residing inside hydro-magmatic explosion craters (Anselmetti et al., 2009, Moernaut et al., 2010, Zolitschka et al., 2013). Detailed 3D lake floor relief images from multibeam bathymetric data allow the identification of a wide range of gravity reworking processes in many parts of the lake (Fig. 2A, Chapron et al., 2010). Localized vertical cliffs along the lake slopes are related to the submerged parts of outcropping subaerial lavas. Scattered boulders are associated with previous rock falls deposits. All around the lake, numerous incised channels (i.e., canyons) correspond to subaquatic continuities of terrestrial springs, gullies and stream flows (Fig. 1B). The slope map (Fig. 2B) illustrates the flat central basin $\left(0-6^{\circ}\right)$ surrounded by steep slopes $\left(>36^{\circ}\right)$. The asymmetric aspect of maar Lake Pavin is underlined by gentle slopes $\left(0-12^{\circ}\right)$ on its northern side creating a plateau (Fig. 2). On the northern side of the lake, one significant feature of the basin is the $350 \mathrm{~m}$ wide fresh slide scar clipping the edge of a plateau characterized by more gentle slopes. These 3D bathymetric views, combined with high-resolution subbottom profiler images from a dense grid survey (Fig. 3A, Chapron et al., 2012), allow us to define four main sedimentary environments in the lake. The littoral environment corresponds to the area between the shoreline and $26 \mathrm{~m}$ water depth where slopes are mid to high $\left(12-30^{\circ}\right)$. On the subbottom profiler data, a specific acoustic facies can be characterized by a downslope thickening transparent facies capped by a high-amplitude reflection at the water interface (Fig. 3B and 4). On the northern side of 
the lake, between 26 and 55 m water depth, the crater material has an irregular morphology with gentle slopes $\left(0-12^{\circ}\right)$ draped by an up to $5 \mathrm{~m}$ thick sedimentary sequence made of two contrasting acoustic facies: (1) a stratified and continuous facies with low-amplitude reflections locally on top of (2) a chaotic to transparent unit (Fig. 3B, 3C and 3D). This sequence reaches the southern part of the plateau where it is interrupted by a slope failure related to the slide scar. Between 55 and $90 \mathrm{~m}$ water depth, the slopes are very steep $\left(>36^{\circ}\right)$ and prevent any sedimentation, but erosion and transport processes are indicated by the presence of series of canyons. Over $90 \mathrm{~m}$ water depth, acoustic waves $(12 \mathrm{kHz})$ were not able to penetrate the basin sedimentary fill due to high gas contents in the sediment but the 3-D bathymetric view exhibits a circular and flat basin, with low relief areas on the southeastern side. The best subbottom images of this flat basin have been provided by previous studies using a $3.5 \mathrm{kHz}$ acoustic source. During this campaign, $1 \mathrm{~m}$ of diatomite has been described by developing a stratified facies with low amplitude and continuous reflections (Chapron et al., 2010).

\subsection{Littoral sedimentation ( 0 - $26 \mathrm{~m}$ water depth)}

At 20 m water depth, core PAV09-C5 (N45 29.93'; E2 ${ }^{\circ} 53.32^{\prime} ;$ Fig. 5 and 6 A) shows a massive brownish unit matching the littoral acoustic facies (Fig. 4). Two erosive layers have been identified (sandy layers at $9 \mathrm{~cm}$ depth and leaf debris with sands at $18 \mathrm{~cm}$ depth, Chapron et al., 2012) and dated cal. AD $1190 \pm 30$ (RDL1) and cal. AD $665 \pm 50$ (RDL2), respectively (Tab.1).

Core PAV10-E (N45 29.92'; E2 ${ }^{\circ} 53.35^{\prime}$; Fig. 5 and 6B) collected at 17 m water depth shows two contrasting units in this sedimentary environment that have been identified with DSR and, primarily, with first derivative spectra analyses (FDS) represented by color changes in the spectral map. From top to bottom, unit PAV10-I is similar to PAV09-C5. Spectrophotometric analyses reveal high $a^{*}$ values (red/green band spectra), indicating a high iron content, in accordance with iron oxy-hydroxides proxies d445 and d525 (Debret et al., 2011). However, this unit shows weak to medium MS values and a TOC content between 
5 and $8 \%$. A sharp transition is observed by the presence of a sandy layer underlined by a peak of MS (RDL3). The bottom of the core is made of more than $50 \mathrm{~cm}$ of laminated brownish facies (in-situ diatomite) with low MS values but up to $11 \%$ TOC content (unit PAV10-II). At this level, the transition from diatomite to littoral unit with an intercalated sandy layer is interpreted as the result of an abrupt environmental change at this site. Its stratigraphic position around $20 \mathrm{~cm}$ depth is close to RDL2 identified in the nearby core PAV09-C5 at the same depth.

\subsection{Plateau sedimentation (26 - $55 \mathrm{~m}$ water depth)}

At the location of core PAV08 (N45 $29.86^{\prime}$; E2 ${ }^{\circ} 53.24^{\prime}$; Fig. 5), subbottom profiles illustrate the superposition of a stratified facies with a draping geometry on a chaotic to transparent facies (Fig. 3 and 4). As detailed in Chapron et al. (2010, 2012), this composite sedimentary sequence corresponds to two main units identified in PAV08 (Fig. 7A). Firstly, a $97 \mathrm{~cm}$ thick in-situ diatomite (PAV08-I) corresponding to the stratified acoustic facies with low-reflectivity (Fig. 3) and then a massive dark brownish deposit rich in leaf debris with a volcanic sandy layer (PAV08-II), corresponding to a mass-wasting deposit (MWD) or slump following the classification of Mulder and Cochonat (1996), hereafter labeled RDL6. This instantaneous deposit covers a thin unit again made of diatomite (PAV08-III, not visible on seismic images) laid on volcanic gravels and pebbles in a volcanic sandy matrix corresponding to the Pavin crater material and matching the acoustic substratum on acoustic profiles (Fig. 3, PAV08-IV in Fig. 7A). This onset of diatomite sedimentation has been dated $6940 \pm 90$ cal. BP (Tab.1, Chapron et al., 2010), suggesting that lake formation and sedimentation processes started soon after the Pavin eruption around 7000 years ago. Along the core, TOC values are medium to high inside the diatomite units (4 to $8 \%$ in PAV08-I and around $8 \%$ in PAV08-III) whereas the MWD shows TOC values up to $20 \%$.

Figures 7B and 7C illustrate the upper diatomite deposit above RDL6. The close-up of PAV08 top-core (i.e. PAV08-P1 in Fig. 7C) highlights two light brownish layers (4-6 cm depth and $16-23 \mathrm{~cm}$ depth), indicated by color changes in the spectral map, high iron content proxy 
values ( $a^{*}$ parameter, d445 and d525, Debret et al., 2011 and references therein) and lower TOC and $\mathrm{HI}$ values than the actual in-situ diatomite. Such remarkable differences are uncommon in diatomite sedimentation in Lake Pavin and lead us to interpret these layers as reworked units (RDLs) originating from the littoral environment. Within the in-situ diatomite, two radiocarbon dates (Tab. 1) allow us to compute an age-depth model for the upper sequence of PAV08 (Fig. 7B), and date these light brownish layers at cal. AD $1915 \pm 5$ (RDL4) and to cal. AD $1700 \pm 15$ (RDL5). The age of RDL6 has also been calculated from leaves and plant debris sampled above it, at the transition with the in-situ diatomite that dated cal. AD $620 \pm 30$ (Fig. 7B, Chapron et al., 2010).

\subsection{Basin deposits (> $90 \mathrm{~m}$ water depth)}

Due to the high gas content in the lake basin sediments, no $12 \mathrm{kHz}$ acoustic image is available for the study of sediment architecture (Fig. 4). However, one long piston core (PAV12, Fig. 5) and one short gravity core (PAV09-B1, Fig. 5) have been collected in the center part of the basin (N45 $29.44^{\prime}$; E2 ${ }^{\circ} 53.18^{\prime}$, Fig. 1). For core PAV12, visual observations and multi-proxy analyses highlight four main lithozones (Fig. 8) whereas core PAV09-B1 contains laminated sediment (in-situ diatomite) characterized by fluctuations in iron proxies, with highest values for $a^{*}, d 445$ and $d 525$ on the top-core (Fig. 9). In this core, MS exhibits generally low values except for three centimetric peaks at 56-58, 67-70 and $90 \mathrm{~cm}$ depth matching silty layers (Fig. 9). Such layers are not present in core PAV12 and are therefore attributed to local turbidites originating from canyons on the slopes (Fig. 2A) and are hereafter labeled RDL7, 8 and 9, respectively. The extension of the layers farther in the basin appears limited because their identification is restricted to this core. One can also note RDL9 presents an unusual iron-rich signature with elevated d445 and d525 values.

From 0 to $207 \mathrm{~cm}$ depth, the upper unit of PAV12 (PAV12-I) contains laminated sediments (in-situ diatomite) with mid to high TOC content (4-9\%) and high values of d445 and d525 iron proxies (Fig. 8). This is in agreement with a previous $198 \mathrm{~cm}$ long core described in the same environment by Stebich et al., (2005) and Schettler et al., (2007). Unit PAV12-II 
displays a succession of various lithological facies with, from top to bottom, a light green massive unit, some disturbed brownish lamina with an erosive base, a dark green massive unit and a more than 2-m thick massive dark brown unit with an erosive sandy base covering a disturbed brownish unit made of highly disrupted diatomite lamina. The total thickness of unit PAV12-II exceeds $4 \mathrm{~m}$ and is interpreted as a MWD, labeled RDL10, characterized by a high variability in spectrophotometric parameters and organic content along with one age reversal (Tab. 1, Fig. 8). Interestingly, the spectral map shows a high content in iron proxies for the light green unit at the top of RDL10 in contrast with other sedimentary facies in this unit and thus could relate to a second instantaneous deposit overlying a former one. This hypothesis is supported by the presence of an erosive layer at $288 \mathrm{~cm}$ depth but the absence of background sedimentation between the light green unit (top) and the dark brown unit (bottom) precludes distinguishing different instantaneous deposits in this complex sedimentary architecture. From 625 to $1045 \mathrm{~cm}$ depth, a second continuous record of diatomite is identified (PAV12-III). Unlike the bottom of PAV12-II, this diatomite unit shows preserved lamina unaffected by the impact of the upper RDL10 described above. Inside this unit, Rock-Eval results indicate increasing $\mathrm{TOC}$ and $\mathrm{HI}$ content from the base to $800 \mathrm{~cm}$ depth, followed by a slight decrease until the top (mean values are TOC $=10 \%$ and $\mathrm{HI}=600$ mg.HC.g ${ }^{-1}$ TOC). However, TOC values remain higher than in the upper organic unit (PAV12I). From $1045 \mathrm{~cm}$ to the base of the core, sediment exhibits a basal unit (PAV12-IV) formed of (1) finely laminated volcano-clastic sediments and (2) massive grey material made of coarse sands and silts at the base with a fining upward sequence with homogenous grey deposits. This sequence includes four turbidites deposits (RDL11, 12, 13 and 14) interbedded with lacustrine sediments, probably transported down to the deep basin through gullies and canyons incised into the Pavin crater rim (Fig. 2A). Their organic content is very low (0 to $2 \%)$ and iron proxies reaches high values, underlining the mineral aspect of this core unit (Fig. 8). 
We used the revised calendar age chronology obtained by varve counting from a nearby freeze-core collected in 2001 (FC01, Schettler et al., 2007) to assign an age for each RDL identified in cores PAV12 and PAV09-B1. This chronology has a significant accuracy but remains "floating" in our dataset due to the absence of stratigraphic markers. Assuming uniform in-situ diatomite sedimentation across the basin, the varve chronology established from 0 to $197 \mathrm{~cm}$ depth in FC01 has been converted to an equivalent depth interval in core PAV12, between 10 and $207 \mathrm{~cm}$ depth, as illustrated in Fig. 9 by a dashed line. The $10 \mathrm{~cm}$ offset is supported by the top-most sedimentation rate of $1 \mathrm{~cm} . \mathrm{yr}^{-1}$ (Schettler et al., 2007) and corresponds to sediment accumulated during the time interval between coring campaigns (i.e., 10 years). With their large uncertainties, radiocarbon ages sampled in cores PAV12 and PAV09-B1 also support this method (Fig. 9). In the absence of uncertainties in the varve chronology, we multiply the offset $(10 \mathrm{~cm})$ by the mean accumulation rate of FC01 $\left(3.7{\mathrm{yr} . \mathrm{cm}^{-}}^{-}\right.$ $\left.{ }^{1}\right)$ to assign error bars for each RDL. Therefore, from top to bottom, the three turbidites have been dated to cal. AD $1860 \pm 20$ (RDL7), cal. AD $1825 \pm 20$ (RDL8) and cal. AD $1770 \pm 20$ (RDL9). Such error bars appear elevated for a varve chronology but are suitable considering the lack of stratigraphic markers between sedimentary cores. The age of the MWD (RDL10) identified in core PAV12 is most likely close to the oldest age referenced in the varve chronology (i.e., cal. AD $1280 \pm 20$ ). The lower organic unit PAV12-III highlights a succession of continuous laminated diatomite where radiocarbon dates performed on leaf debris indicates an age of $1635 \pm 35$ cal. BP for the top of this unit and $5980 \pm 55 \mathrm{cal}$. BP for the bottom (Tab. 1, Fig. 8). In consequence, event RDL10 eroded or incorporated ca. 1000 years of in-situ diatomite. No radiocarbon date is available at the bottom of this unit. However, considering a synchronous onset for diatomite sedimentation at the scale of the whole lake, the transition from PAV12-IV (basal unit) to PAV12-III (lower organic unit) could be contemporaneous to bulk sediment dated at the bottom of PAV08 on the plateau (i.e., cal. BP $6940 \pm 90$, Fig. 7A). In this scenario, the succession of turbidites identified within the basal unit would then have been deposited just after the crater formation ca. 7000 years ago, during a short time window (RDL11, 12, 13 and 14). 


\section{EXTREME EVENTS RECORDED IN LAKE PAVIN}

Within the five sedimentary cores retrieved in the littoral, the plateau and the basin, a total of fourteen RDLs have been listed (see 4.2 to 4.4). Clastic turbidites (RDL11, 12, 13 and 14) are only documented in PAV12. Their ages are poorly constrained but are clustered in the early stage of Lake Pavin formation, when it used to be a young crater without vegetation cover in the catchment. In such environments, increases in precipitation rates may have enhanced erosion of fresh volcanic products. In this setting, lake level variations contributed to slope instabilities that may have disturbed unstable material to promote gravity reworking processes and the formation of turbidity currents.

Considering dating uncertainties, we highlight a succession of six major sedimentary events (SE) during the last two millennia through one or several synchronous RDLs across the lacustrine environments (Fig. 10). This event stratigraphy is thus relevant to illustrate the past extreme phenomena occurring in Lake Pavin.

\subsection{AD 600 crater outburst and lake-level drop (SE1)}

The oldest event in our chronology is the ca. AD 600 event (SE1, Fig. 10) associated with a sandy layer in the littoral (RDL2 in PAV09-C5) and a slump deposit on the plateau (RDL6 in PAV08). In the littoral environment, both cores PAV09-C5 and PAV10-E contain a RDL around $20 \mathrm{~cm}$ depth. Unfortunately, the low amount of macro organic remains found in PAV10-E precludes radiocarbon dating for RDL3 that cannot be directly connected to SE1. However, core PAV10-E shows an abrupt transition between the littoral and the diatomite unit. According to the acoustic stratigraphy illustrating a transition from littoral to diatomite at a water depth of $26 \mathrm{~m}$, this transition constitutes a sedimentary evidence for a lake-level fall of at least $9 \mathrm{~m}$, as core PAV10-E was collected at a water depth of $17 \mathrm{~m}$ (Fig. 4). This hypothesis is confirmed by RE pyrolysis performed on this core, showing a shift in organic composition toward a less hydrogenated and more oxygenated organic matter. This change is illustrated in the Van Krevelen-type plots by a mix of aquatic (type II) and terrestrial (type 
III) compounds and in the S2/TOC diagram by a drop in hydrogen-related parameter S2 and TOC (Fig. 11A). This evolution might be attributed to a shift in the organic source, for example cyanobacteria vs. diatoms (Ariztegui et al., 2001), but can also reflect oxidation during the transport and burial of organic matter (Meyers and Lallier-Vergès, 1999). Following Talbot and Livingstone (1989), this second hypothesis reflects more oxidative conditions linked to a lower water level during sedimentation. The most probable explanation for this shift in RE signatures in Lake Pavin is a subaerial exposure of former littoral sediments leading to an oxidation before their erosion, transport and sedimentation in present-day lacustrine environments.

As a lake-level fall affects the whole lake, similar trends are observed between lower and upper organic units (i.e., diatomite) in cores PAV08 and PAV12 (Fig. 11B and 11C) collected on the plateau and the central basin, respectively. In both cases, the organic signature of the upper diatomite is made of less hydrogenated matter with low amounts of TOC, such as in the littoral unit in core PAV10-E. On the plateau, this signature appears after the RDL6 deposition; in the basin, it is recorded above the erosive RDL10. Consequently, the lake-level fall is associated with the oldest RDL occurring at ca. AD 600 in core PAV08. Considering the Pavin volcanic setting, a crater rim breach is the likeliest explanation for an abrupt drawdown of the water level (Fig. 12A). A deep incision is clearly visible today inside the northern crater walls at the present lake outlet (Fig. 1B).

Inside the lake, SE1 has been associated with a major slump that is clearly visible on acoustic images on the plateau (Fig. 3) and described in core PAV08 as RDL6. Based on the dense grid of acoustic profiles on the plateau, an isopach map of this MWD has been drawn and a volume of $87,000 \mathrm{~m}^{3}$ has been calculated (Fig. 12A). This estimate represents a minimum value because no acoustic images are available to constrain its possible extent in the basin. Outside the lake, this scenario is in agreement with the observation of slackwaters and outwash fan deposits between the Lake Pavin outlet and the couze Pavin river, less than $400 \mathrm{~m}$ away (Fig. 12B). On a west-east transect along the couze Pavin River, these deposits 
have been identified on seven outcrops. They are characterized by numerous boulders, blocks and pebbles made of Pavin crater material in a sandy volcanic matrix (Fig. 12C and 12D). Such deposits provide evidence for a major outburst flood overflowing the downstream river in consequence of the breaching rim. Similar events have already been described worldwide in many crater lakes and represent substantial hazards in volcanic environments (Manville et al., 2007, Manville, 2010). On the aerial photography (IGN), grey-level variations highlighted the outburst flood deposits outside in the couze Pavin valley with the deflection of the original river bed over $500 \mathrm{~m}$ long. At the confluence of the outlet with the couze Pavin River, the outburst flood deposit is covered by grassland and is eroding a pluricentimetric peat deposit developed above sandy to silty fluvial deposits (Fig. 12C and 12D). A bulk sample of the upper part of this eroded peat has been dated and represents a maximum age (Urlaub et al., 2013) of $1765 \pm 55$ cal. BP for the upper erosive deposit (Tab. 1).

Assuming a general cylindrical shape for maar Lake Pavin, the estimated water volume can be calculated by multiplying the lake drawdown $(9 \mathrm{~m})$ by the current surface area $\left(0.44 \mathrm{~km}^{2}\right)$. Therefore, the water discharge is estimated at 3.96 million $\mathrm{m}^{3}$, which is twice the size of the AD 1953 and AD 2007 outburst floods occurring at Ruapehu caldera lake in New Zealand (Tab. 2, Manville, 2010 and references therein), suggesting a catastrophic flash flood downstream in the valley of the couze Pavin River. Following hydraulic equations presented in Walder and O'Connor, 1997, we estimate a peak discharge for this event near $1,500 \mathrm{~m}^{3} . \mathrm{s}^{-}$ 1.

Finally, the presence of two contemporaneous erosive layers (RDL2 in PAV09-C5 and probably RDL3 in PAV10-E) in the littoral environment suggest shorelines erosion resulting from wave action (Moore et al., 2006, Garduño-Monroy et al., 2011 and Kremer et al., 2014). Following the outburst and the associated MWD inside the lake, waves should have locally swept the shorelines to scatter sandy layers and leaf debris across the littoral environment. Alternatively, waves induced by subaquatic mass movements may have impacted the outlet to trigger a rim collapse and the following lake-level drop (Chapron et al., 2010). 


\section{2. $A D 1300$ slope failure (SE2)}

SE2 corresponds to the ca. AD 1300 event (Fig. 10) and is represented by a large MWD in the central basin (RDL10 in PAV12). Subaquatic morphology highlights a large slide scar clipping the edge of the plateau (Fig. 3A), which corresponds to an inherited structure after slope failure at this site. This recent landform is certainly connected to RDL10 identified in PAV12 and indicates a complex mixing of sedimentary facies resulting from gravity reworking transport from the plateau. The complex sedimentary architecture and absence of acoustic images makes it impossible to estimate the extent and calculate the volume of sediment deposited in the basin after this slope failure.

Otherwise, the presence of a $10 \mathrm{~cm}$-thick diatom bloom layer just above RDL10 (Fig. 5) suggests deep-water mixing and upwelling of nutrient-rich waters to enhance algal productivity (Zhang et al., 2014). As with the AD 600 event, violent waves would have resulted from this large subaquatic slide; the waves are the likeliest explanation for reworked sand deposits (RDL1) at core PAV09-C5 site. The absence of overlap between the two RDLs in Fig. 10 is due to different sampling strategies for radiocarbon dating. In the basin, RDL10 has been dated with the age-depth model established for in-situ diatomite above it. Conversely, the age of RDL1 has been obtained by leaf debris sampled within the sandy layer. According to Urlaub et al. (2013), this sampling method indicates a maximum age which explains the 100 years gap between RDL1 and RDL10 (Fig. 10).

\subsection{Recent historical events (SE3, 4, 5 and 6)}

In PAV08 core, RDL5 and RDL4 have been identified by color changes with lower TOC and HI values but higher iron content and dated cal. AD $1700 \pm 15$ and cal. AD $1915 \pm 5$, respectively (Fig. 6). Interestingly, these two dates are close to visual descriptions of unusual behavior of Lake Pavin waters. As detailed in Meybeck et al (accepted), in AD 1783 and AD 1936, witnesses reported sudden "color change from very clear water to yellowish", a smell of sulfur along with "modification of the nature of lake waters which looks silty [...] and 
corrosive". Similar observations were made after the Nyos catastrophe in August 1986 (Le Guern et al., 1992) and during overturn phenomena in other meromictic lakes (Cabassi et al., 2014). Moreover, red colored waters have been recently observed at the surface of Lake Nyos, where pumping systems installed to avoid degassing hazards led to the oxidation of dissolved ferrous iron accumulated in the monimolimnion (Rouwet et al., 2014, Tassi and Rouwet, 2014). The time gap between historical descriptions (AD 1783 and AD 1936) and RDLs in Lake Pavin (cal. AD $1700 \pm 15$ and cal. AD $1915 \pm 5$ ) does not allow a perfect linkage, but likely reflects a lack of accuracy in the age-depth model of core PAV08. Moreover, their iron-rich signatures support the idea of bottom mixing events following a lake overturn, when the oxidation of dissolved ferrous iron present in the monimolimnion turned the entire water column red. Therefore, iron-rich deposits can be recorded in the mixolimnion at core PAV08 site. In the deep basin, the silty turbidite (RDL9), dated to cal. AD $1770 \pm 20$ is characterized by a peak in iron oxy-hydroxides proxies (Fig. 9). Its signature and its age connect it more probably to the lake overturn documented in AD 1783 (Meybeck et al., accepted).

Considering the dating accuracy of the core PAV08 age-depth model, RDL5 and RDL9 could be correlated from the plateau to the basin (Fig. 10) and thus gathered in a sedimentary event (SE3).

During the $\mathrm{XIX}$ th century, two other thin turbidites have been highlighted by MS values in the basin (RDL7 and RDL8) and interpreted as two additional (but more limited) sedimentary events. They were dated at cal. AD $1825 \pm 20$ (SE4) and cal. AD $1860 \pm 20$ (SE5), respectively (Fig. 10). Finally, the topmost iron-rich deposit identified in core PAV08 (RDL4) represents the most recent event (SE6), dated at cal. AD $1915 \pm 5$.

\subsection{Processes involved in triggering sedimentary events}

The occurrence of sedimentary events in lacustrine archives depends on various gravity reworking processes that follow slope failures. The geomorphological setting of the lake and 
the shear strength of the sediments are two essential parameters controlling the sediment stability. A slope failure and the associated gravity reworking processes may thus be the result of a natural overloading of slope sediments but can also be triggered by waves, gas discharges, earthquakes and/or changes in sediment interstitial pressure following rapid lake-level fluctuations (e.g., Chapron et al., 2004, Guyard et al., 2007, Fanetti et al., 2008, Anselmetti et al., 2009, Moernaut et al., 2014). Bottom mixing events as potential trigger for reworked sediments in meromictic lakes have also been mentioned in the previous section.

Seismic triggering of subaqueous mass-movements is attested by the correlation between a sedimentary event and an earthquake, but this method is rarely suitable beyond the last millennium due to the lack of available historical sources (Schnellmann et al., 2002, Strasser et al., 2013, Moernaut et al., 2014, Howarth et al., 2014). In the Auvergne area, an overview of the historical seismicity provides potential candidates to trigger some sedimentary events identified in Lake Pavin (Fig. 1A). During the XIX ${ }^{\text {th }}$ century, two moderate earthquakes (MSK V) occurred beneath the Mont-Dore massif at Chambon-sur-Lac in AD 1844 and at MontDore in AD 1863 and probably correspond to SE4 and SE5 recorded in the basin, respectively. The weak earthquake (MSK IV) that occurred at La Bourboule in AD 1921 is close to event SE6 and could also have acted as a trigger. However, the spectral signature of SE6 (identical to SE3) makes it more likely to be a product of a bottom-mixing event witnessed in AD 1936 (Meybeck et al., accepted). On the other hand, three stronger seismic events (MSK VI-VII) occurred on the southern part of the Limagne Fault in AD 1833 and AD 1892, 30 kilometers east of Lake Pavin and could also be involved in SE4 and SE5; for example, the shake map of the AD 1892 event illustrates an intensity of V-VI at Lake Pavin (www.sisfrance.net). During this century, recurrence time for earthquakes was relatively low. Therefore, given dating uncertainties for sedimentary events in the lake basin record, it is impossible to associate each event layer to one specific earthquake.

It has been shown that earthquakes can trigger synchronous deposits over large areas or disconnected basins in both marine and continental settings (Anselmetti et al., 2009, 
Goldfinger et al., 2007, Talling, 2014, Howarth et al., 2014). In the Mont Dore area, lacustrine studies are sparse but ongoing investigations in nearby lakes Chauvet, Montcineyre and Guéry (i.e. within 20 kilometers, Fig. 1A) suggest a regional event near AD 1300 (Chapron et al., 2012, Chassiot et al., submitted). We thus propose that a paleo-earthquake was the trigger for synchronous mass-movements in surrounding lakes, including the slope failure at the edge of the plateau in Lake Pavin (SE2). Such an event triggered a large subaqueous mass-movement that caused part of the plateau deposits to collapse down to the basin (RDL10), generating high energy waves inside the crater that reworked sandy layers (RDL1) on the littoral environment.

Several natural factors can be responsible for triggering the crater rim failure that occurred in AD 600. The outlet represents a weak point in the crater walls as it is made with unconsolidated materials. Outflowing waters controlled by climate might alter the inner porosity of fresh volcanic fallout, especially during periods with enhanced precipitations and high lake levels. At this date, intense rainfalls have been described by historian Gregorius of Tours in Auvergne and may explain the crater collapse and the consequent outburst flood at Lake Pavin. More generally, this event matches a cold and humid period for Western Europe evidenced by higher detrital phases in Lake Le Bourget (Debret et al., 2010) and enhanced glacial activity in the Alps (Simonneau et al., 2014). It also corresponds to a period of higher lake-levels (Magny, 2007). However, this humid period is not visible in nearby Lake Aydat record (Fig. 1A, Lavrieux et al., 2013). Another hypothesis to explain this dam break is a seismic event, but no sign of earthquake has been noticed for this period in historical (Lambert et al., 1997, Stucchi et al., 2013) or in nearby lacustrine (Lavrieux et al., 2013) archives. In any case, the present-day morphology may be inherited from backward erosion in the outflowing gully upon high-discharge events.

\section{NATURAL HAZARDS ASSESSMENT}




\subsection{Lake Pavin sensitivity to the regional seismicity}

The regional tectonic setting is marked by two seismogenic elements: the Mont-Dore massif and the Limagne fault (Fig. 1). Plotting MSK scale intensity at epicenter against the distance defines the lake sensitivity to earthquakes (Nomade et al., 2005, Wilhelm et al., 2015). In Figure 13, we present a synthesis of historical earthquakes with available intensities and an epicenter in a radius of 100 kilometers from Lake Pavin (Lambert et al., 1997, Stucchi et al., 2013). An empirical limit has been defined as a log-function, separating the potentially recorded from unrecorded earthquakes in Lake Pavin (Fig. 13A). This log-function is related to attenuation models for seismic waves with distance established for active chains and stable continental regions in France (Bakun and Scotti, 2006). Even if these models do not concern the French Massif Central, we assume an analogous model to compare our results with similar studies focusing on alpine lakes (Petersen et al., 2014, Wilhelm et al., 2015).

The potentially recorded earthquakes have a minimum epicentral intensity of $V$ on the MSK scale (Fig. 13A) which corresponds to a minimum threshold to trigger mass-movements in Lake Pavin. These seismic events are related to nearby seismogenic areas of the Mont-Dore massif and of the southern part of the Limagne fault. In contrast, the largest earthquakes identified in the northern part of this fault (AD 1477 and AD 1490) are not recorded in Lake Pavin. This may be due to a too great distance $(35 \mathrm{~km})$, but it is recognized that earthquakes can easily affect sediment stability at this distance (Nomade et al., 2005, Wilhelm et al., 2015). As one major slide occurred less than 200 years before (SE2), sedimentary reloading on the plateau may have not been sufficient to destabilize the sedimentary units during the earthquakes that occurred in the late $\mathrm{XV}^{\text {th }}$ century.

In Lake Pavin, the minimal threshold intensity appears weaker than in similar studies performed in alpine lakes (Fig. 13B, Petersen et al., 2014, Wilhelm et al., 2015), suggesting that Lake Pavin is highly sensitive to earthquakes, with the exception of the $\mathrm{XV}^{\text {th }}$ century events that were probably due to their occurrence shortly after the AD 1300 event. This high sensitivity can be attributed to the specific context of Lake Pavin. Its steep slopes resulting 
from a volcanic explosion may enhance the generation of landslides triggered by external factors. Also, the organic and gas-rich sediment essentially made of diatomite with a loose texture results in a low cohesion material that can be easily removed during gravity reworking phenomena (Chapron et al., 2012). Since the dam break in AD 600, the interstitial pore pressure has been significantly changed as a result of the $9 \mathrm{~m}$ lake-level lowering, making Lake Pavin more sensitive to record the next tectonic events. During the $\mathrm{XIX}^{\text {th }}$ century, artificial drainages and the consequent lake-level drop of $4 \mathrm{~m}$ (Eusébio and Reynouard, 1925) may also have increase the lake sensitivity to earthquakes at this period.

Finally, at least three historical earthquakes (two in the XIX ${ }^{\text {th }}$ century and one in AD 1300) may have triggered subaqueous slides and fine-grained turbidites in the Lake Pavin record in the last 2,000 years. Such a series of events is not excessive compared with lacustrine records located in continental active chains like the Alps (Nomade et al., 2005, Strasser et al., 2013, Wilhelm et al., 2015). Conversely, Lake Pavin contains more earthquake-triggered deposits than any other archive in the French Massif Central for the same time window. For example, only one pre-historical MWD has been reported near AD 180 in volcanic Lake Aydat (Lavrieux et al., 2013).

\subsection{Implication for hazards assessment in volcanic lakes}

The Lake Pavin sedimentary record contains a wide range of various extreme events that occurred during the last 2,000 years, with implications for past, present and future natural hazards in similar environments. The most obvious examples are the possible consequences of such subaqueous mass-movements occurring both inside and outside the lake. In maar lakes, they can be easily reflected along the lake shores and eventually may cause a lake outburst at the outlet (Chapron et al., 2010). These outburst floods resulted in a sudden lake drainage with the generation of hyperconcentrated flows (i.e. lahar-type floods) downstream of the crater (Funiciello et al., 2003, Manville et al., 2007, Manville, 2010), along with an abrupt lake-level drop that affected sediment stability and lake sensitivity to record the following earthquakes. Even if lake Pavin is a small maar lake $\left(0.44 \mathrm{~km}^{2}\right)$, this rapid drainage 
event generated an outburst with significant consequence compared with other similar events documented worldwide in intra-caldera lakes (Tab.2), generating a maximum water discharge estimated at $1500 \mathrm{~m}^{3} \cdot \mathrm{s}^{-1}$ during the overspill.

Another evidence for past natural hazards in Lake Pavin is the presence of iron-rich sedimentary events in the plateau deposit that reflect possible lake overturns in recent history of the lake. In such volcanic environments, a rollover mechanism occur when lake stratification is disturbed by subaqueous slides (Sigurdsson et al., 1987), by the cooling and sinking of shallow waters and/or strong winds (Cabassi et al., 2014), although strong winds are unlikely within this lake surrounded by vegetated crater walls. If the initial stored gas volume is large, which is currently not the case in Lake Pavin, the expulsion of dissolved gases can drive the formation of a killer gas cloud such as in tropical lakes Monoun and Nyos (Kling et al., 1987). If the store gas volume is low, lethal risk is limited for humans, but the biosphere can be severely damaged by sulfidic waters. Obvious examples are fish kill events in Lake Averno, Italy (Caliro et al., 2008) and in Hule and Rìo Cuarto lakes, Costa Rica (Cabassi et al. 2014). As Lake Pavin was actually devoid of fish before their introduction in $A D$ 1859, no fish kill has been reported. Nevertheless, the very rich history and legendary accounts of the lake reveal a latent fear of the area since the mid-XVI $\left.\right|^{\text {th }}$ century, and probably much before. Such histories may explain the original name Paven (or Pavens, which means terrifying) for this lake and are comparable to other historical reports about maar lake waters in Germany and Italy (Meybeck, accepted).

In Lake Pavin, low gas concentration in the monimolimnion suggests a limited current hazard today. However, a direct consequence of large subaquatic mass-movements is the generation of high density flows that can disturb the lake water stratification and potentially trigger a catastrophic lake overturn (Sigurdsson et al., 1987, Chapron et al., 2010). As massmovements can be triggered by earthquakes, such events need to be considered for risk assessment in the vicinity of $\mathrm{CO}_{2}$-rich volcanic lakes located in tectonically active areas, where similar degassing events and/or repeated lahars have been reported during the 
Holocene (Funiciello et al., 2003, Anzidei et al., 2008, De Benedetti et al., 2008, Caracausi et al., 2009, Chiodini et al., 2012).

\section{CONCLUSIONS}

The combination of several hydroacoustic mapping techniques together with multi-proxies analyses performed on five cores illustrate the evolution of the sedimentary fill, environmental changes and natural hazards in Lake Pavin. Across the lake, the spatiotemporal distribution of sedimentological features suggest various type of mass-wasting deposits, eventually associated to past extreme events during the last 2,000 years.

(1) At ca. AD 600, the northern crater wall of Lake Pavin collapsed under possible climate deterioration to generate an outburst flood downstream of the crater along with a slump deposit inside the lake. The following $9 \mathrm{~m}$ lake-level drop has been demonstrated by major shifts in organic sedimentation patterns in the entire lake.

(2) At ca. $A D$ 1300, an earthquake-triggered subaquatic mass-movement affected the edge of the plateau and resulted in a large deposit in the basin that probably generated violent waves eroding the lake shore. Numerical simulations are needed to evaluate the potential generation of waves triggered by subaqueous mass-movements and their consequence in maar Lake Pavin.

(3) During the XIX $X^{\text {th }}$ century, two historical earthquakes have been recorded by thin turbidites in the basin. The presence of these layers outlines the potential of the sedimentary archives of the lake to record regional seismicity, which is a function of both internal (i.e., slopes degree, type of sediments and lake-level fluctuations) and external factors (i.e., earthquakes distance and intensity).

(4) Three iron-rich sedimentary events appear to match historical observations of yelloworange-colored waters in the lake. Such deposits could reflect past bottom-mixing events with oxidation of dissolved ferrous iron abundant in the monimolimnion through the entire water column. One forthcoming challenge could be to test this assumption on analogous 
meromictic lakes that have undergone recent lake overturns. So far, the question "How a limnic eruption is recorded in the sediments?" remains open to debate.

In meromictic crater lakes like Lake Pavin, such past extreme events may represent a large volume of reworked sediments. The occurrence of the event layers in the sedimentary archive indicates past natural hazards with substantial risk for waves, outburst floods or lake overturns with possible gas bursts. The triggering mechanisms involved in this type of masswasting deposits could affect lake morphology and water chemistry to drive major changes in the sedimentary record. Therefore, it is essential to better understand these mechanisms before considering future investigations on Lake Pavin. More generally, this study underlined the fact that, even after thousands of years without magmatic activity, a wide range of interconnected hazards can occur in volcanic lakes.

\section{ACKNOWLEDGMENTS}

This work has been possible thanks to the financial support of CNRS-INSU in the framework of DICENTIM project and by the Canadian Foundation for Innovation and the Ministère de l'éducation (Québec) for an instrument grant to P.L. Leo Chassiot benefitted of a PhD grant from the Région Centre. Authors would like to thank BRGM for multibeam bathymetric data, EDYTEM laboratory for piston coring operations and the OSUC Master students for gravity coring operations and laboratory assistance. We acknowledge D. Jézéquel, P. Boivin and P. Lavina for fruitful scientific discussions. We also wish to thank V. Manville and an anonymous reviewer for their constructive comments. 


\section{REFERENCES}

Aeschbach-Hertig, W., Hofer, M., Kipfer, R., Imboden, D.M., Wieler, R., 1999. Accumulation of mantle gases in a permanently stratified volcanic Lake (Lac Pavin, France). Geochimica et Cosmochimica Acta 63, 3357-3372.

Albéric, P., Jézéquel, D., Bergonzini, L., Chapron, E., Viollier, E., Massault, M., Michard, G., 2013. Carbon Cycling and Organic Radiocarbon Reservoir Effect in a Meromictic Crater Lake (lac Pavin, Puy-De-Dôme, France). Radiocarbon 55, 1029-1042.

Anselmetti, F.S., Ariztegui, D., De Batist, M., Gebhardt, A.C., Haberzettl, T., Niessen, F., Ohlendorf, C., Zolitschka, B., 2009. Environmental history of southern Patagonia unravelled by the seismic stratigraphy of Laguna Potrok Aike. Sedimentology 56, 873-892. doi:10.1111/j.1365-3091.2008.01002.x

Anzidei, M., Carapezza, M.L., Esposito, A., Giordano, G., Lelli, M., Tarchini, L., 2008. The Albano Maar Lake high resolution bathymetry and dissolved CO2 budget (Colli Albani volcano, Italy): Constrains to hazard evaluation. Journal of Volcanology and Geothermal Research 171, 258-268. doi:10.1016/j.jvolgeores.2007.11.024

Ariztegui, D., Chondrogianni, C., Lami, A., Guilizzoni, P., Lafargue, E., 2001. Lacustrine organic matter and the Holocene paleoenvironmental record of Lake Albano (central Italy). Journal of Paleolimnology 26, 283-292. doi:10.1023/A:1017585808433

Assayag, N., Jézéquel, D., Ader, M., Viollier, E., Michard, G., Prévot, F., Agrinier, P., 2008. Hydrological budget, carbon sources and biogeochemical processes in Lac Pavin (France): Constraints from $\delta 180$ of water and $\delta 13 \mathrm{C}$ of dissolved inorganic carbon. Applied Geochemistry 23, 2800-2816. doi:10.1016/j.apgeochem.2008.04.015

Bakun, W.H., Scotti, O., 2006. Regional intensity attenuation models for France and the estimation of magnitude and location of historical earthquakes. Geophysical Journal International 164, 596-610. doi:10.1111/j.1365-246X.2005.02808.x

Baumont, D., Scotti, O., 2011. The French Parametric Earthquake Catalogue (FPEC) based on the best events of the SisFrance macroseismic database-version 1.1. 
IRSN/DEI/2011-012

Behar, F., Beaumont, V., Penteado, H.D.B., 2001. Rock-Eval 6 technology: performances and developments. Oil \& Gas Science and Technology 56, 111-134.

Blaauw, M., 2010. Methods and code for "classical" age-modelling of radiocarbon sequences. Quaternary Geochronology 5, 512-518. doi:10.1016/j.quageo.2010.01.002

Bonhomme, C., Poulin, M., Vinçon-Leite, B., Saad, M., Groleau, A., Jézéquel, D., Tassin, B., 2011. Maintaining meromixis in Lake Pavin (Auvergne, France): The key role of a sublacustrine spring. Comptes Rendus Geoscience 343, 749-759. doi:10.1016/j.crte.2011.09.006

Bourdier, J.-L., 1980. Contribution à l'étude volcanologique de deux secteurs d'intérêt géothermique dans le Mont-Dore: le groupe holocène du Pavin et le massif du Sancy. PhD thesis. Université de Clermont-Ferrand. 180p.

Cabassi, J., Tassi, F., Mapelli, F., Borin, S., Calabrese, S., Rouwet, D., Chiodini, G., Marasco, R., Chouaia, B., Avino, R., Vaselli, O., Pecoraino, G., Capecchiacci, F., Bicocchi, G., Caliro, S., Ramirez, C., Mora-Amador, R., 2014. Geosphere-Biosphere Interactions in Bio-Activity Volcanic Lakes: Evidences from Hule and Rìo Cuarto (Costa Rica). PLoS ONE 9, e102456. doi:10.1371/journal.pone.0102456

Caliro, S., Chiodini, G., Izzo, G., Minopoli, C., Signorini, A., Avino, R., Granieri, D., 2008. Geochemical and biochemical evidence of lake overturn and fish kill at Lake Averno, Italy. Journal of Volcanology and Geothermal Research, Volcanic lakes and environmental impacts of volcanic fluids 178, 305-316. doi:10.1016/j.jvolgeores.2008.06.023

Camus, G., Michard, G., Olive, P., Boivin, P., Desgranges, P., Jezequel, D., Meybeck, M., Peyrus, J.C., Vinson, J.M., Viollier, E., Kornprobst, J., 1993. Risques d'eruption gazeuse carbonique en Auvergne. Bulletin de la Societe Geologique de France 164, 767-781. 
Caracausi, A., Nuccio, P.M., Favara, R., Nicolosi, M., Paternoster, M., 2009. Gas hazard assessment at the Monticchio crater lakes of Mt. Vulture, a volcano in Southern Italy. Terra Nova 21, 83-87. doi:10.1111/j.1365-3121.2008.00858.x

Chapron, E., Van Rensbergen, P., De Batist, M., Beck, C., Henriet, J.P., 2004. Fluid-escape features as a precursor of a large sublacustrine sediment slide in Lake Le Bourget, NW Alps, France. Terra Nova 16, 305-311. doi:10.1111/j.1365-3121.2004.00566.x

Chapron, E., Albéric, P., Jézéquel, D., Versteeg, W., Bourdier, J.-L., Sitbon, J., 2010. Multidisciplinary characterisation of sedimentary processes in a recent maar lake (Lake Pavin, French Massif Central) and implication for natural hazards. Natural Hazards and Earth System Science 10, 1815-1827. doi:10.5194/nhess-10-18152010

Chapron, E., Ledoux, G., Simonneau, A., Albéric, P., St-Onge, G., Lajeunesse, P., Boivin, P., Desmet, M., 2012. New Evidence of Holocene Mass Wasting Events in Recent Volcanic Lakes from the French Massif Central (Lakes Pavin, Montcineyre and Chauvet) and Implications for Natural Hazards, in: Yamada, Y., Kawamura, K., Ikehara, K., Ogawa, Y., Urgeles, R., Mosher, D., Chaytor, J., Strasser, M. (Eds.), Submarine Mass Movements and Their Consequences. Springer Netherlands, Dordrecht, pp. 255-264.

Chassiot, L., Chapron, E., Di Giovanni, C., Lajeunesse, P., Tachikawa, T., Garcia, M., Bard, E. Historical seismicity of the Mont Dore volcanic province (Auvergne, France) unraveled by a regional lacustrine investigation: new insights about lake sensitivity to earthquakes. Submitted to Sedimentary Geology.

Chiodini, G., Tassi, F., Caliro, S., Chiarabba, C., Vaselli, O., Rouwet, D., 2012. Timedependent $\mathrm{CO} 2$ variations in Lake Albano associated with seismic activity. Bulletin of Volcanology 74, 861-871. doi:10.1007/s00445-011-0573-x

Cotel, A.J., 1999. A trigger mechanism for the Lake Nyos disaster. Journal of volcanology and geothermal research 88, 343-347. 
De Benedetti, A.A., Funiciello, R., Giordano, G., Diano, G., Caprilli, E., Paterne, M., 2008. Volcanology, history and myths of the Lake Albano maar (Colli Albani volcano, Italy). Journal of Volcanology and Geothermal Research 176, 387-406. doi:10.1016/j.jvolgeores.2008.01.035

Debret, M., Chapron, E., Desmet, M., Rolland-Revel, M., Magand, O., Trentesaux, A., BoutRoumazeille, V., Nomade, J., Arnaud, F., 2010. North western Alps Holocene paleohydrology recorded by flooding activity in Lake Le Bourget, France. Quaternary Science Reviews 29, 2185-2200. doi:10.1016/j.quascirev.2010.05.016

Debret, M., Sebag, D., Desmet, M., Balsam, W., Copard, Y., Mourier, B., Susperrigui, A.-S., Arnaud, F., Bentaleb, I., Chapron, E., Lallier-Vergès, E., Winiarski, T., 2011. Spectrocolorimetric interpretation of sedimentary dynamics: The new "Q7/4 diagram." Earth-Science Reviews 109, 1-19. doi:10.1016/j.earscirev.2011.07.002

Eusébio, A., Reynouard, J., 1925. Le Lac Pavin et le Creux de Soucy. Station Limnologique de Besse, Besse, 55p.

Evans, W.C., Kling, G.W., Tuttle, M.L., Tanyileke, G., White, L.D., 1993. Gas buildup in Lake Nyos, Cameroon: The recharge process and its consequences. Applied Geochemistry 8, 207-221. doi:10.1016/0883-2927(93)90036-G

Evans, W.C., White, L.D., Tuttle, M.L., Kling, W.C., Tanyileke, G., Michel, R.L., 1994. Sixyears of change at Lake Nyos, Cameroon, yield clues to the past and cautions for the future. http://doi.org/10.2343/geochemj.28.139.

Fanetti, D., Anselmetti, F.S., Chapron, E., Sturm, M., Vezzoli, L., 2008. Megaturbidite deposits in the Holocene basin fill of Lake Como (Southern Alps, Italy). Palaeogeography, Palaeoclimatology, Palaeoecology 259, 323-340. doi:10.1016/j.palaeo.2007.10.014

Funiciello, R., Giordano, G., De Rita, D., 2003. The Albano maar lake (Colli Albani Volcano, Italy): recent volcanic activity and evidence of pre-Roman Age catastrophic lahar events. Journal of Volcanology and Geothermal Research 123, 43-61. doi:10.1016/S0377-0273(03)00027-1 
Garduño-Monroy, V.H., Soria-Caballero, D.C., Israde-Alcántara, I., Hernández Madrigal, V.M., Rodríguez-Ramírez, A., Ostroumov, M., Rodriguez-Pasqua, M.A., ChaconTorres, A., Mora-Chaparro, J.C., 2011. Evidence of tsunami events in the paleolimnological record of Lake Patzcuáro, Michoácan, Mexico. Geofisica Internacional 50, 147-161.

Goldfinger, C., Morey, A.E., Nelson, C.H., Gutiérrez-Pastor, J., Johnson, J.E., Karabanov, E., Chaytor, J., Eriksson, A., 2007. Rupture lengths and temporal history of significant earthquakes on the offshore and north coast segments of the Northern San Andreas Fault based on turbidite stratigraphy. Earth and Planetary Science Letters 254, 9-27. doi:10.1016/j.epsl.2006.11.017

Guyard, H., Chapron, E., St-Onge, G., Anselmetti, F.S., Arnaud, F., Magand, O., Francus, P., Mélières, M.-A., 2007. High-altitude varve records of abrupt environmental changes and mining activity over the last 4000 years in the Western French Alps (Lake Bramant, Grandes Rousses Massif). Quaternary Science Reviews 26, 2644-2660. doi:10.1016/j.quascirev.2007.07.007

Howarth, J.D., Fitzsimons, S.J., Norris, R.J., Jacobsen, G.E., 2014. Lake sediments record high intensity shaking that provides insight into the location and rupture length of large earthquakes on the Alpine Fault, New Zealand. Earth and Planetary Science Letters 403, 340-351. doi:10.1016/j.epsl.2014.07.008

Kling, G.W., Clark, M.A., Wagner, G.N., Compton, H.R., Humphrey, A.M., Devine, J.D., Evans, W.C., Lockwood, J.P., Tuttle, M.L., Koenigsberg, E.J.,1987. The 1986 lake Nyos disaster in Cameroon, East Africa. Science 236, 169-175. doi: 10.1126/science.236.4798.169

Kremer, K., Marillier, F., Hilbe, M., Simpson, G., Dupuy, D., Yrro, B.J.F., Rachoud-Schneider, A.-M., Corboud, P., Bellwald, B., Wildi, W., Girardclos, S., 2014. Lake dwellers occupation gap in Lake Geneva (France-Switzerland) possibly explained by an earthquake-mass movement-tsunami event during Early Bronze Age. Earth and Planetary Science Letters 385, 28-39. doi:10.1016/j.epsl.2013.09.017 
Lambert, J., Bernard, P., Czitrom, G., Dubié, J.-Y., Godefroy, P., Levret-Albaret, A., 1997. Les tremblements de terre en France, Hier, aujourd'hui, demain... BRGM, 196p.

Lavrieux, M., Disnar, J.-R., Chapron, E., Bréheret, J.-G., Jacob, J., Miras, Y., Reyss, J.-L., Andrieu-Ponel, V., Arnaud, F., 2013. 6700 yr sedimentary record of climatic and anthropogenic signals in Lake Aydat (French Massif Central). The Holocene 23, 1317-1328. 0959683613484616.

Le Guern, F., Shanklin, E., Tebor, S., 1992. Witness accounts of the catastrophic event of August 1986 at Lake Nyos (Cameroon). Journal of Volcanology and Geothermal Research 51, 171-184. doi:10.1016/0377-0273(92)90067-N

Magny, M., 2007. Lake levels study. West-Central-Europe, in: Encyclopedia of Quaternary Science. Elsevier, pp. 1389-1399.

Manville, V., Hodgson, K.A., Nairn, I.A., 2007. A review of break-out floods from volcanogenic lakes in New Zealand. New Zealand Journal of Geology and Geophysics 50, 131-150. 0028-8306/07/5002-0131

Manville, V., 2010. An overview of break-out floods from intracaldera lakes. Global and Planetary Change 70, 14-23. doi:10.1016/j.gloplacha.2009.11.004

Manville, V., 2015. Volcano-Hydrologic Hazards from Volcanic Lakes, in: Rouwet, D., Christenson, B., Tassi, F., Vandemeulebrouck, J. (Eds.), Volcanic Lakes. Springer Berlin Heidelberg, Berlin, Heidelberg, pp. 21-71.

Meybeck, M., accepted. (a) Pavin, a rich but fragmented history (AD 200 - 2011). (b) Dragons, fairies and miracles at Pavin and other European maar lakes. In: T.NsimeGando et al., Pavin Lake, Springer eds.

Meyers, P.A., Lallier-vergés, E., 1999. Lacustrine Sedimentary Organic Matter Records of Late Quaternary Paleoclimates. Journal of Paleolimnology 21, 345-372. doi:10.1023/A:1008073732192

Moernaut, J., Verschuren, D., Charlet, F., Kristen, I., Fagot, M., De Batist, M., 2010. The seismic-stratigraphic record of lake-level fluctuations in Lake Challa: Hydrological stability and change in equatorial East Africa over the last 140kyr. Earth and 
Planetary Science Letters 290, 214-223. doi:10.1016/j.epsl.2009.12.023

Moernaut, J., Daele, M.V., Heirman, K., Fontijn, K., Strasser, M., Pino, M., Urrutia, R., De Batist, M., 2014. Lacustrine turbidites as a tool for quantitative earthquake reconstruction: New evidence for a variable rupture mode in south central Chile. J. Geophys. Res. Solid Earth 119, 2013JB010738. doi:10.1002/2013JB010738

Moore, J.G., Schweickert, R.A., Robinson, J.E., Lahren, M.M., Kitts, C.A., 2006. Tsunamigenerated boulder ridges in Lake Tahoe, California-Nevada. Geology 34, 965. doi:10.1130/G22643A.1

Mott, R.., Woods, A.., 2010. A model of overturn of $\mathrm{CO}_{2}$ laden lakes triggered by bottom mixing. Journal of Volcanology and Geothermal Research 192, 151-158. doi:10.1016/j.jvolgeores.2010.02.009

Mulder, T., Cochonat, P., 1996. Classification of offshore mass movements. Journal of Sedimentary Research 66, 43-57. doi:10.1306/D42682AC-2B26-11D7$8648000102 C 1865 D$

Nomade, J., Chapron, E., Desmet, M., Reyss, J.-L., Arnaud, F., Lignier, V., 2005. Reconstructing historical seismicity from lake sediments (Lake Laffrey, Western Alps, France). Terra Nova 17, 350-357. doi:10.1111/j.1365-3121.2005.00620.x

Olive, P., Boulègue, J., 2004. Biogeochemical study of a meromictic lake: Pavin lake, France. Géomorphologie: relief, processus, environnement 10, 305-316. doi:10.3406/morfo.2004.1226

Petersen, J., Wilhelm, B., Revel, M., Rolland, Y., Crouzet, C., Arnaud, F., Brisset, E., Chaumillon, E., Magand, O., 2014. Sediments of Lake Vens (SW European Alps, France) record large-magnitude earthquake events. Journal of Paleolimnology 51, 343-355. doi:10.1007/s10933-013-9759-x

Reimer, P.J., Bard, E., Bayliss, A., Beck, J.W., Blackwell, P.G., Bronk Ramsey, C., Buck, C.E., Cheng, H., Edwards, R.L., Friedrich, M., others, 2013. IntCal13 and Marine13 radiocarbon age calibration curves $0-50,000$ years cal BP. Radiocarbon 55, 1869 1887. 
Rouwet, D., Tassi, F., Mora-Amador, R., Sandri, L., Chiarini, V., 2014. Past, present and future of volcanic lake monitoring. Journal of Volcanology and Geothermal Research 272, 78-97. doi:10.1016/j.jvolgeores.2013.12.009

Schettler, G., Schwab, M.J., Stebich, M., 2007. A 700-year record of climate change based on geochemical and palynological data from varved sediments (Lac Pavin, France). Chemical Geology 240, 11-35. doi:10.1016/j.chemgeo.2007.01.003

Schnellmann, M., Anselmetti, F.S., Giardini, D., McKenzie, J.A., Ward, S.N., 2002. Prehistoric earthquake history revealed by lacustrine slump deposits. Geology 30, 1131. doi:10.1130/0091-7613(2002)030<1131:PEHRBL>2.0.CO;2

Sigurdsson, H., Devine, J.D., Tchua, F.M., Presser, F.M., Pringle, M.K.W., Evans, W.C., 1987. Origin of the lethal gas burst from Lake Monoun, Cameroun. Journal of Volcanology and Geothermal Research 31, 1-16. doi:10.1016/0377-0273(87)90002-3

Simonneau, A., Chapron, E., Garçon, M., Winiarski, T., Graz, Y., Chauvel, C., Debret, M., Motelica-Heino, M., Desmet, M., Di Giovanni, C., 2014. Tracking Holocene glacial and high-altitude alpine environments fluctuations from minerogenic and organic markers in proglacial lake sediments (Lake Blanc Huez, Western French Alps). Quaternary Science Reviews 89, 27-43. doi:10.1016/j.quascirev.2014.02.008

Stebich, M., Brüchmann, C., Kulbe, T., Negendank, J.F.W., 2005. Vegetation history, human impact and climate change during the last 700 years recorded in annually laminated sediments of Lac Pavin, France. Review of Palaeobotany and Palynology 133, 115133. doi:10.1016/j.revpalbo.2004.09.004

Strasser, M., Monecke, K., Schnellmann, M., Anselmetti, F.S., 2013. Lake sediments as natural seismographs: A compiled record of Late Quaternary earthquakes in Central Switzerland and its implication for Alpine deformation. Sedimentology 60, 319-341. doi:10.1111/sed.12003

Stucchi, M., Rovida, A., Gomez Capera, A.A., Alexandre, P., Camelbeeck, T., Demircioglu, M.B., Gasperini, P., Kouskouna, V., Musson, R.M.W., Radulian, M., Sesetyan, K., Vilanova, S., Baumont, D., Bungum, H., Fäh, D., Lenhardt, W., Makropoulos, K., 
Martinez Solares, J.M., Scotti, O., Živčić, M., Albini, P., Batllo, J., Papaioannou, C., Tatevossian, R., Locati, M., Meletti, C., Viganò, D., Giardini, D., 2013. The SHARE European Earthquake Catalogue (SHEEC) 1000-1899. Journal of Seismology 17, 523-544. doi:10.1007/s10950-012-9335-2

Talbot, M.R., Livingstone, D.A., 1989. Hydrogen index and carbon isotopes of lacustrine organic matter as lake level indicators. Palaeogeography, Palaeoclimatology, Palaeoecology 70, 121-137. doi:10.1016/0031-0182(89)90084-9

Talling, P.J., 2014. On the triggers, resulting flow types and frequencies of subaqueous sediment density flows in different settings. Marine Geology 352, 155-182. doi:10.1016/j.margeo.2014.02.006

Tassi, F., Rouwet, D., 2014. An overview of the structure, hazards, and methods of investigation of Nyos-type lakes from the geochemical perspective. Journal of Limnology 73. doi:10.4081/jlimnol.2014.836

Urlaub, M., Talling, P.J., Masson, D.G., 2013. Timing and frequency of large submarine landslides: implications for understanding triggers and future geohazard. Quaternary Science Reviews 72, 63-82. doi:10.1016/j.quascirev.2013.04.020Viollier, E., Jézéquel, D., Michard, G., Pèpe, M., Sarazin, G., Alberic, P., 1995. Geochernical study of a crater lake (Pavin Lake, France): Trace-element behaviour in the monimolimnion. Chemical Geology 125, 61-72. doi:10.1016/0009-2541(95)00059-U

Walder, J.S., O'Connor, J.E., 1997. Methods for predicting peak discharge of floods caused by failure of natural and constructed earthen dams. Water Resources Research 33, 2337-2348. doi:10.1029/97WR01616

Wilhelm, B., Nomade, J., Crouzet, C., Litty, C., Sabatier, P., Belle, S., Rolland, Y., Revel, M., Courboulex, F., Arnaud, F., Anselmetti, F.S., 2015. Quantified sensitivity of small lake sediments to record historic earthquakes: Implications for paleoseismology. Journal of Geophysical Research: Earth Surface 120, doi:10.1002/2015JF003644

Zhang, X., Scholz, C.A., Hecky, R.E., Wood, D.A., Zal, H.J., Ebinger, C.J., 2014. Climatic control of the late Quaternary turbidite sedimentology of Lake Kivu, East Africa: 
Implications for deep mixing and geologic hazards. Geology 42, 811-814. doi:10.1130/G35818.1

Zolitschka, B., Anselmetti, F., Ariztegui, D., Corbella, H., Francus, P., Lücke, A., Maidana, N.I., Ohlendorf, C., Schäbitz, F., Wastegård, S., 2013. Environment and climate of the last 51,000 years - new insights from the Potrok Aike maar lake Sediment Archive Drilling prOject (PASADO). Quaternary Science Reviews 71, 1-12. doi:10.1016/j.quascirev.2012.11.024 


\section{FIGURES AND TABLES CAPTIONS}

Figure 1: (A) General location and Digital Elevation Model of the studied area with seismotectonic setting (HF: Houiller Fault - LF: Limagne Fault) and volcanic lakes discussed in this study (A: Aydat - C: Chauvet - G: Guéry - M: Montcineyre - P: Pavin). Dates and location of historical earthquakes are indicated by circles. (B) Geomorphologic map of the MontchalPavin volcanic complex with simplified lake bathymetry (Fig. 2) and coring locations (Fig. 5).

Figure 2: (A) 3D bathymetric view of maar Lake Pavin showing the subaquatic floor morphology with a wide range of mass-movement morphologies, modified after Chapron et al. (2010). (B) Slope map of Lake Pavin illustrating the flat central basin surrounded by steep slopes, with a plateau on the northern side.

Figure 3: Grid of high-resolution subbottom profiler data (12 kHz) along the plateau on the northern side of Lake Pavin (A) with transversal surveys illustrating main acoustic facies of sedimentary deposits above the plateau (B, C, and D, after Chapron et al. (2012)).

Figure 4: High-resolution subbottom profile $(12 \mathrm{kHz})$ along a North-South transect inside Lake Pavin showing the acoustic stratigraphy of deposits over the littoral, plateau and basin environments. Dotted lines correspond to the locations of perpendicular profiles given in Fig. 3B, 3C and 3D. Note that the AD1300 slide scar affects the distal part of the AD 600 slump deposit on the plateau.

Figure 5: Long piston cores and short gravity cores collected in the littoral (PAV10-E and PAV09-C5), plateau (PAV08) and basin (PAV12 and PAV09-B1) environments. Lithological facies have been synthesized into sedimentary units, in agreement with acoustic facies (Fig. 3). Rapidly Deposited Layers (RDLs) are also shown and labeled from 1 to 14.

Figure 6: (A) Ages of RDL1 and RDL2 reflected by erosive sandy and leaves layers within the core PAV09-C5 are estimated by calibration results of two radiocarbon ages (Tab.1). (B) Multi-proxies analyses for core PAV10-E highlighting a sharp transition from diatomite toward littoral sedimentation with an intercalated erosive sandy layer (RDL3), as shown by DSR 
measurements, either $\mathrm{a}^{*}$ parameter or iron oxy-hydroxides proxies (d445 or d525), and also by measurements of organic content (TOC).

Figure 7: Signatures of RDLs in core PAV08. (A) TOC content in sedimentary units of core PAV08 with calibrated age for the onset of diatomite sedimentation as detailed by Chapron et al., 2010. (B) Age-depth model for PAV08-I with calibrated ages for RDL4, RDL5 and RDL6. (C) Top core PAV08-P1 with RDL4 and RDL5 underlined by drop in TOC and HI content, but higher values for iron content proxies. Note RDL5 is clearly identified by a light brownish unit on core photograph.

Figure 8: Multi-proxy analyses and radiocarbon dates for core PAV12 showing the succession of an upper organic unit (PAV12-I), a thick MWD (RDL10; PAV12-II), a lower organic unit (PAV12-III) and a basal unit (PAV12-IV) with intercalated turbidites (RDL11, RDL12, RDL13 and RDL14).

Figure 9: Close-up of the top-core PAV12 (left) along with short-core PAV09-B1 showing thin silty turbidites (RDL7, 8, and 9) indicated by maximum values of magnetic susceptibility (MS). Note that RDL9 is in addition characterized by a peak in FDS iron oxy-hydroxides (goethite) proxies documented by d445 and d525 $\mathrm{nm}$. The dashed line refers to a former varve counting performed by Schettler et al. (2007) on cores collected in 1999 and 2001, here validated by radiocarbon dating sampled in cores PAV12 (220 $\pm 30 \mathrm{BP})$ and PAV09-B1 $(150 \pm 30 \mathrm{BP})$, allowing us to assign an age for each RDL. As detailed in the text, the $10 \mathrm{~cm}$ offset is in agreement with the time gap between coring campaigns (i.e., 10 years) and the top-most sedimentation rate in FC01 (1 cm.yr ${ }^{-1}$; Schettler et al., 2007)

Figure 10: Sedimentary events (SE) determined either by one single RDL or by a correlation of synchronous RDLs across the three lacustrine environments (littoral, plateau and basin) in Lake Pavin over the last 2,000 years. Note RDL5 and RDL9 are gathered into one single event (SE3) due to the lack of accuracy in the age-depth model of core PAV08. RDL1 is also interpreted as a reworked unit linked to SE2. See text for details. 
Figure 11: Van Krevelen-type (left) and S2/TOC (right) plots illustrating organic matter signatures for main units in cores PAV10-E (A), PAV08 (B) and PAV12 (C). The three types of organic matter are referenced in the Van-Krevelen-type diagrams. The corresponding poles (algal vs. terrestrial) are indicated in the S2/TOC diagram (Ariztegui et al., 2001). Red/Black circles represent domains corresponding to samples collected in the lower/upper organic units.

Figure 12: (A) Morpho-sedimentary signature of the AD 600 crater outburst flood in the couze Pavin valley (outburst flood deposits delimited by dashed white lines) and in Lake Pavin (MWD). (B) Stratigraphic sequence from upstream (left) to downstream couze Pavin (right). Outcrops numbers are located on Fig. 11A. At the confluence with Lake Pavin outlet, outburst flood deposits from the crater are identified and locally erode peat formation (sites 4, 5 and 7). (C) Photograph of couze Pavin sedimentary sequence. (D) Photograph of breakout flood deposits with blocks of Pavin crater material in a sandy matrix eroding a peat.

Figure 13: (A) Log plot of MSK scale intensity at epicenter vs. distance to Lake Pavin for earthquakes within a radius of $100 \mathrm{~km}$ with error bars location. Black dots show unrecorded earthquakes whereas red squares indicates potential trigger for SE4 and SE5. Dashed line represents the limit between recorded and unrecorded earthquakes, showing required thresholds in MSK epicentral intensity $(\geq V)$. (B) Comparison of lake Pavin sensitivity to earthquakes with other alpine lakes: Vens (VEN), Blanc Aiguilles Rouges (BAR), Foréant (FOR), Anterne (ANT) and Laffrey (LAF) taken from Petersen et al. (2014) and Wilhelm et al. (2015).

Table 1: Material sampled for AMS radiocarbon analyses with conventional (BP) and calibrated (cal. BP) radiocarbon ages using IntCal13 reference curve (Reimer et al., 2013). The number in brackets represents the probability for two-sigma calibration. 
Table 2: Comparison of Lake Pavin outburst flood with others experienced in selected intracaldera lakes (data from Manville, 2010). Peak discharge has been calculated by using empirical equations defined by Walder and O'Connor (1997). 

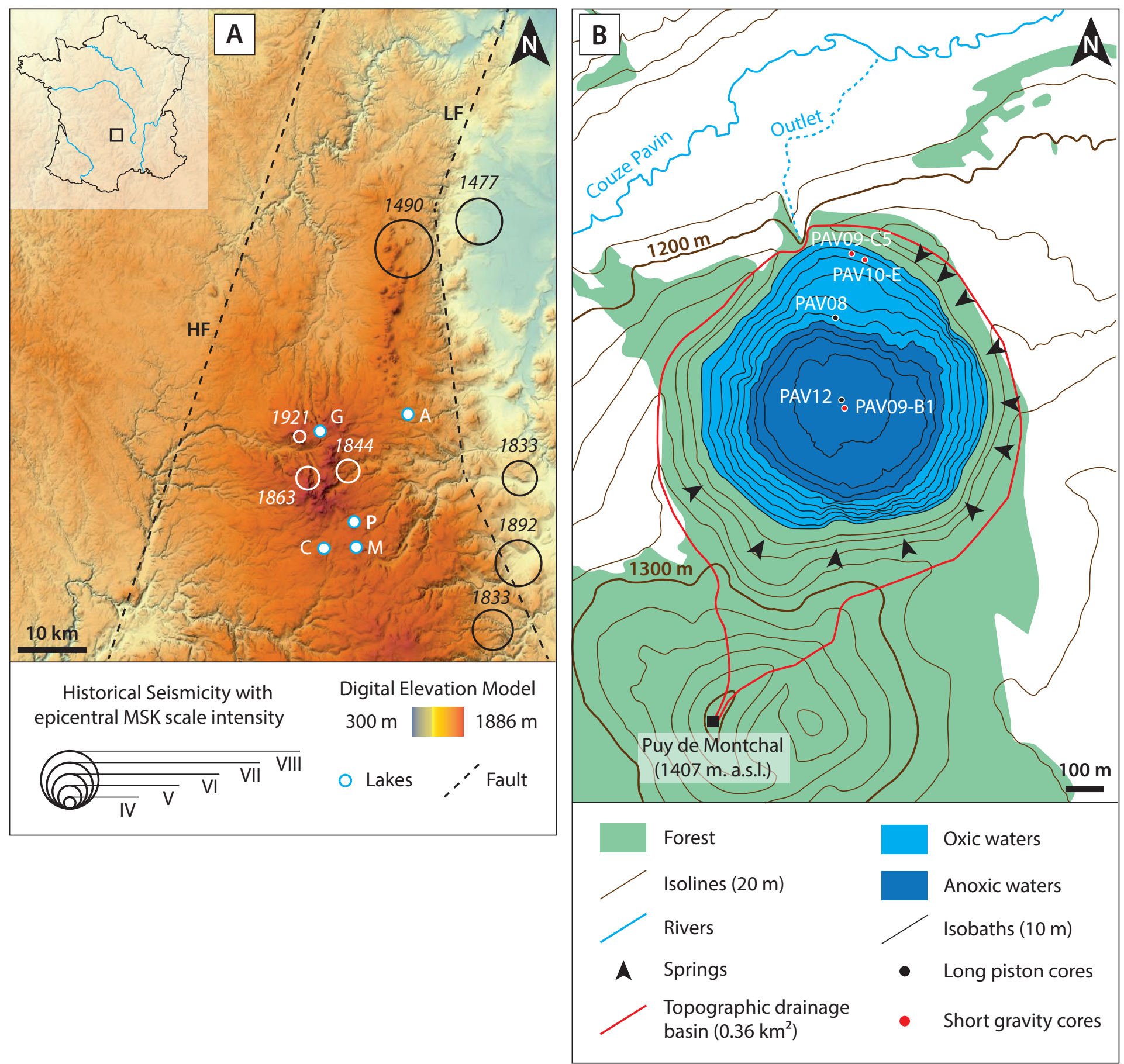


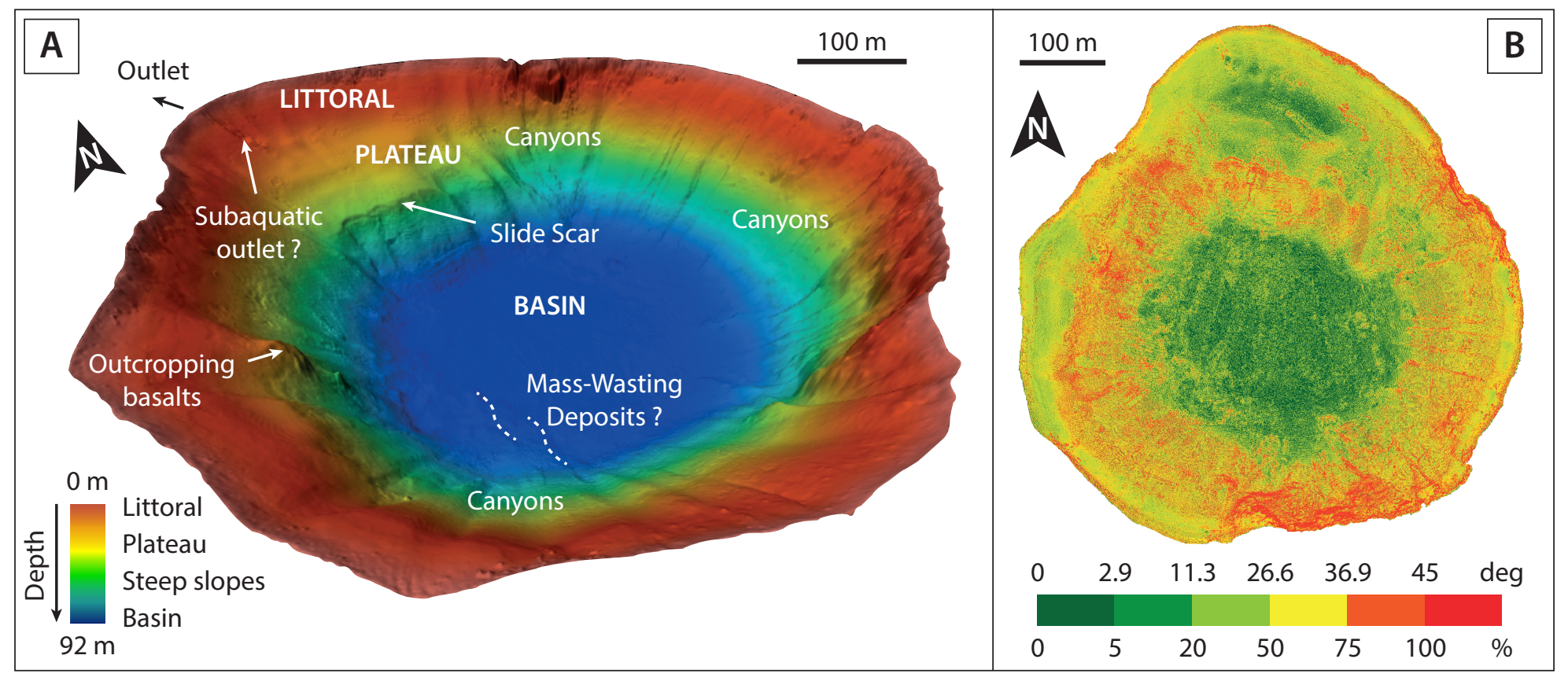




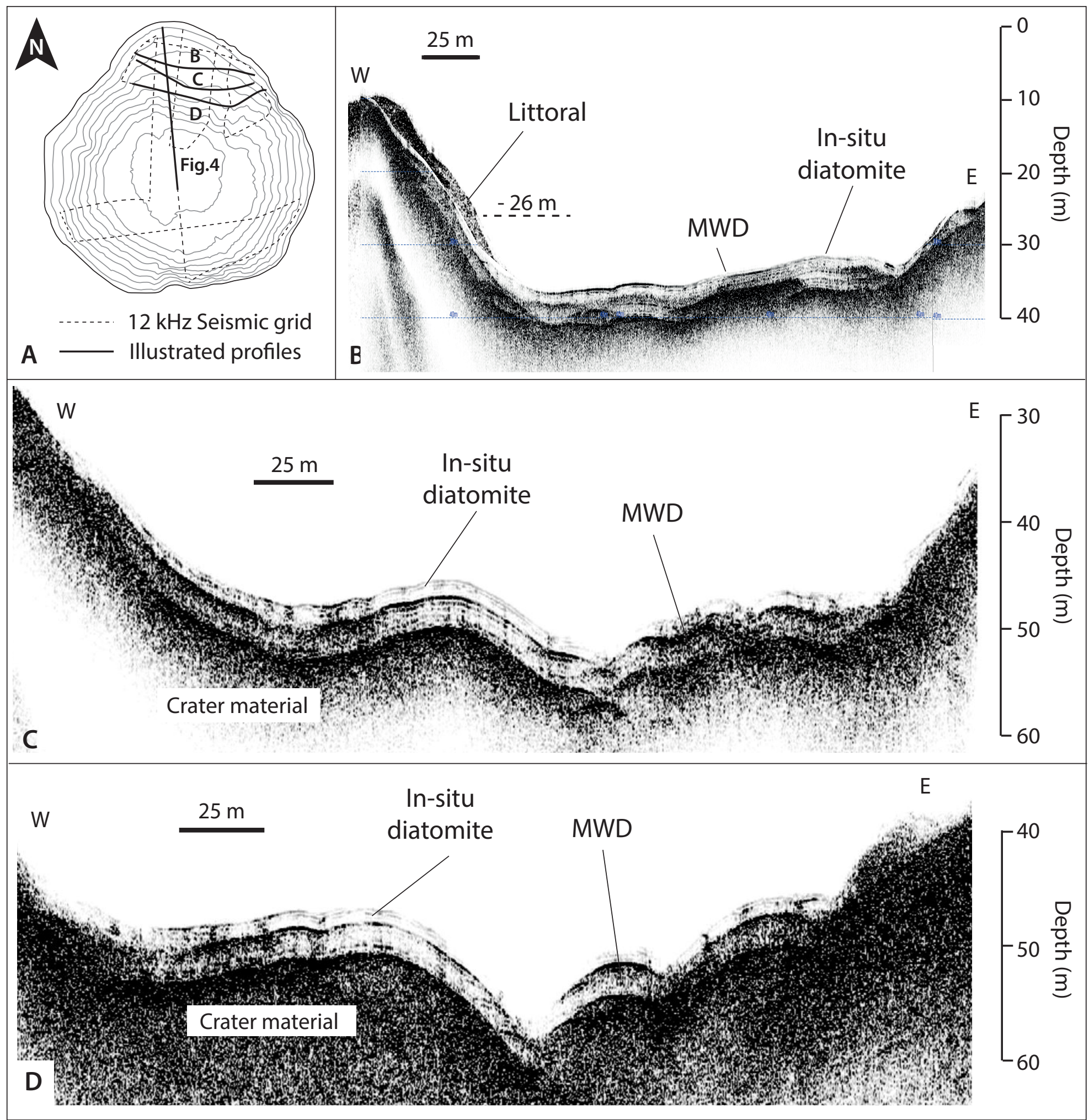




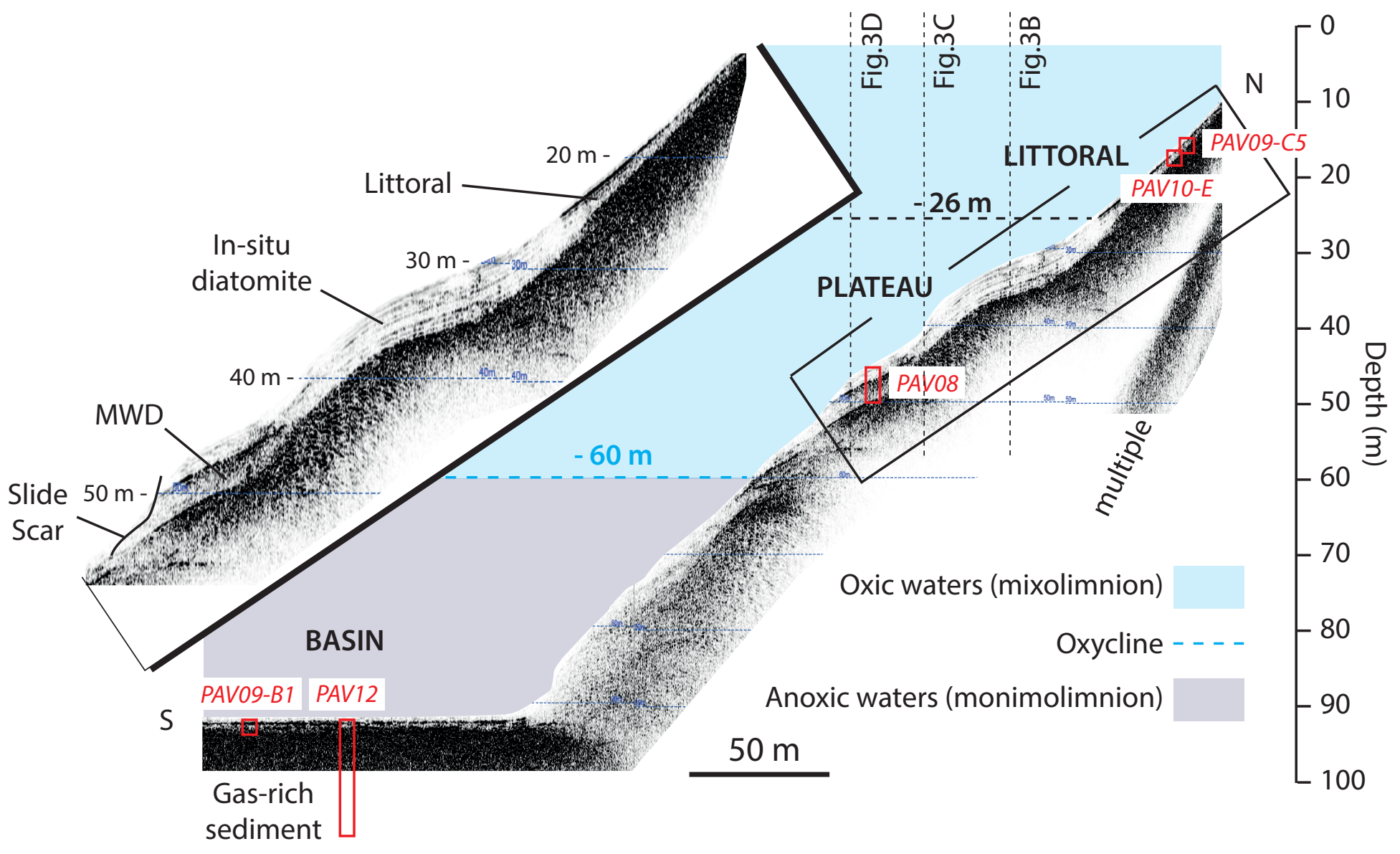




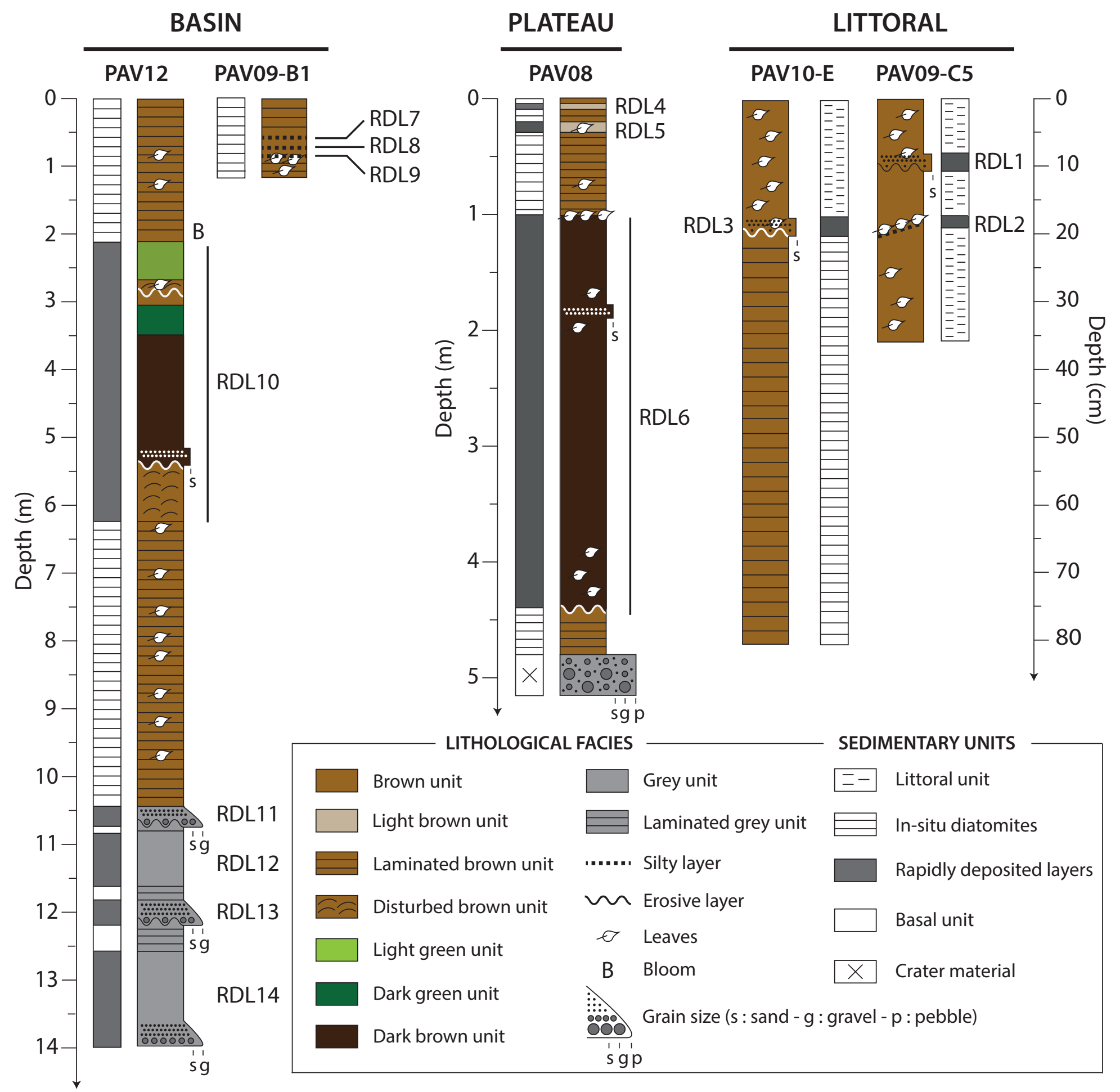




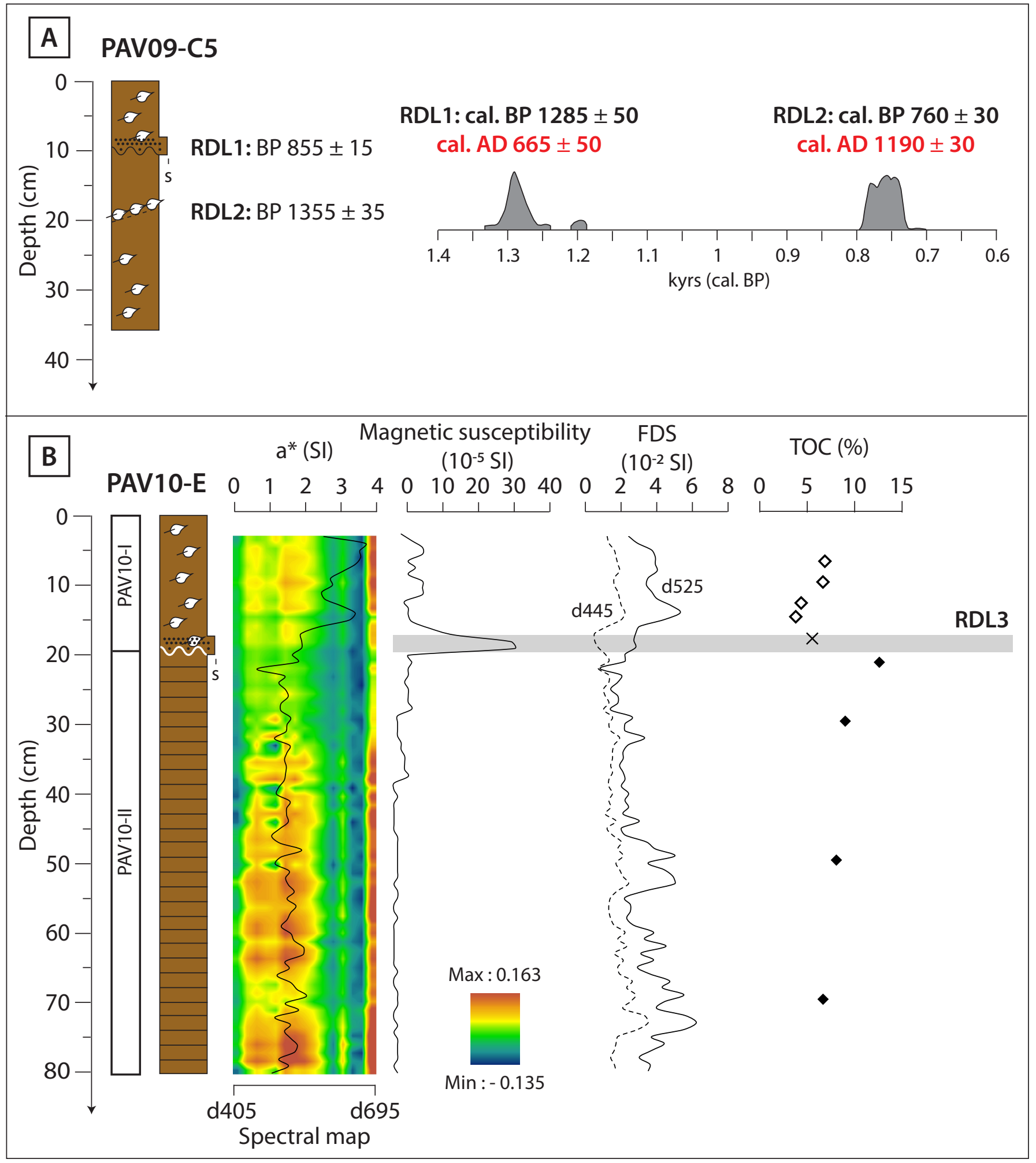




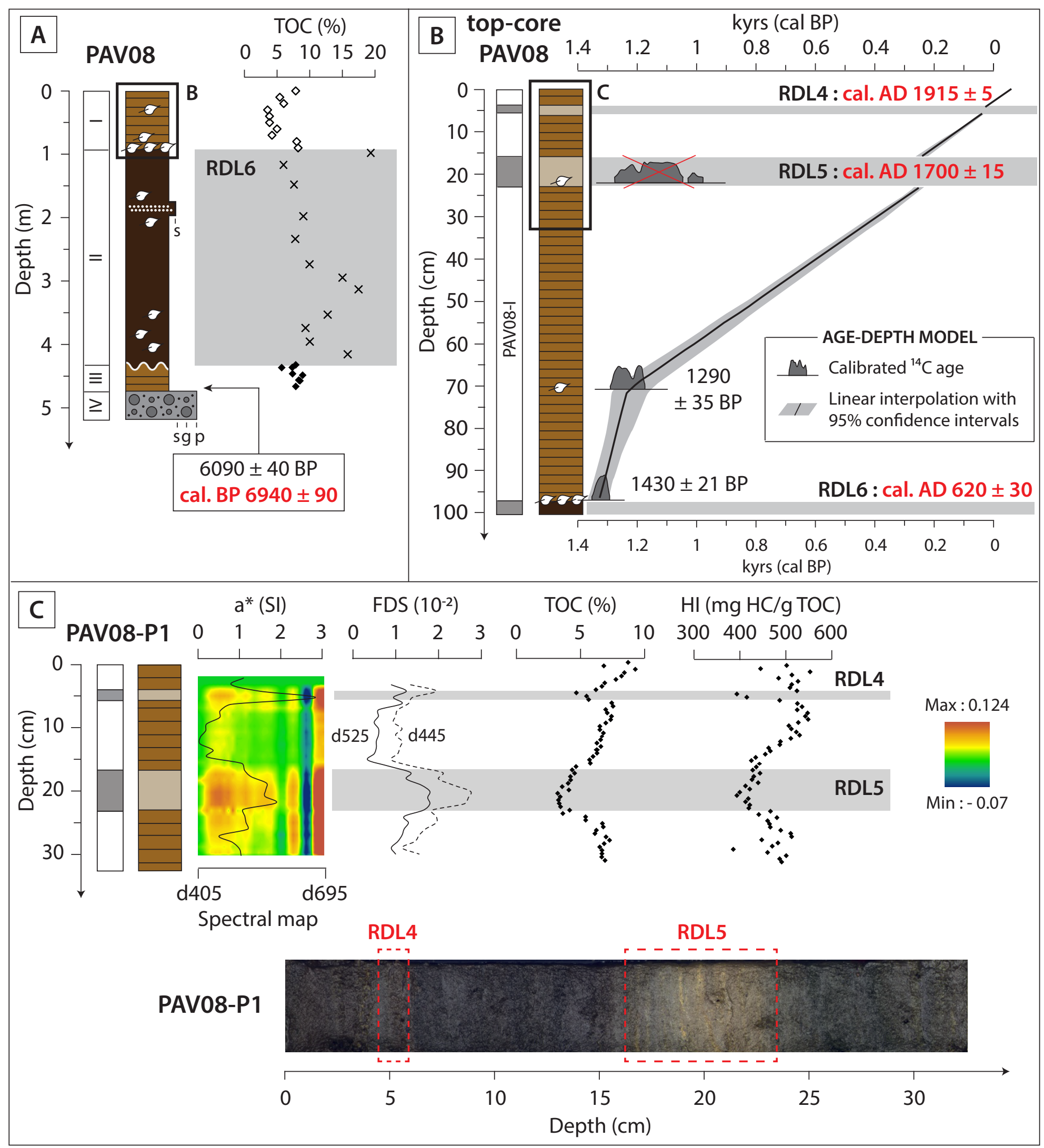




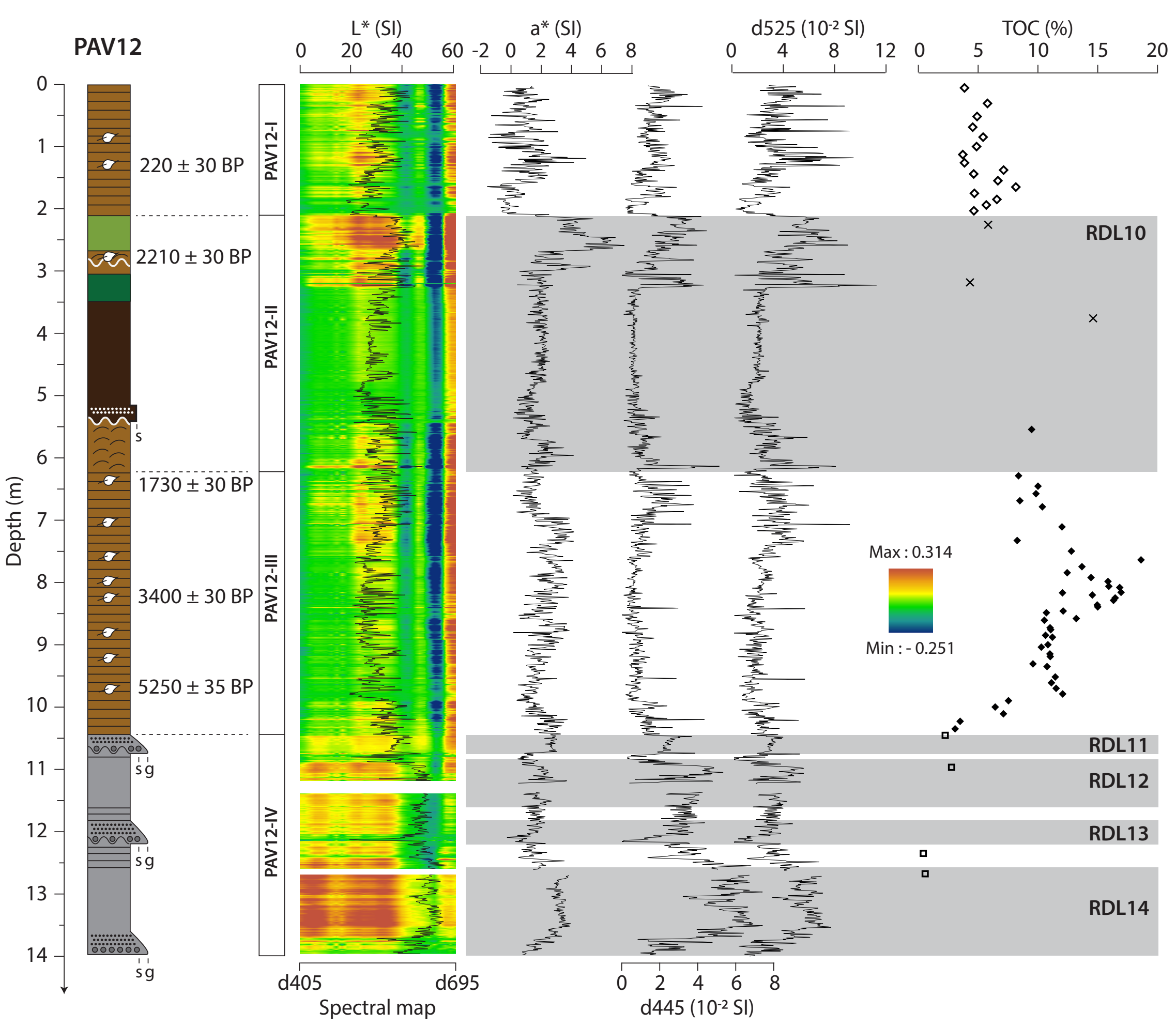




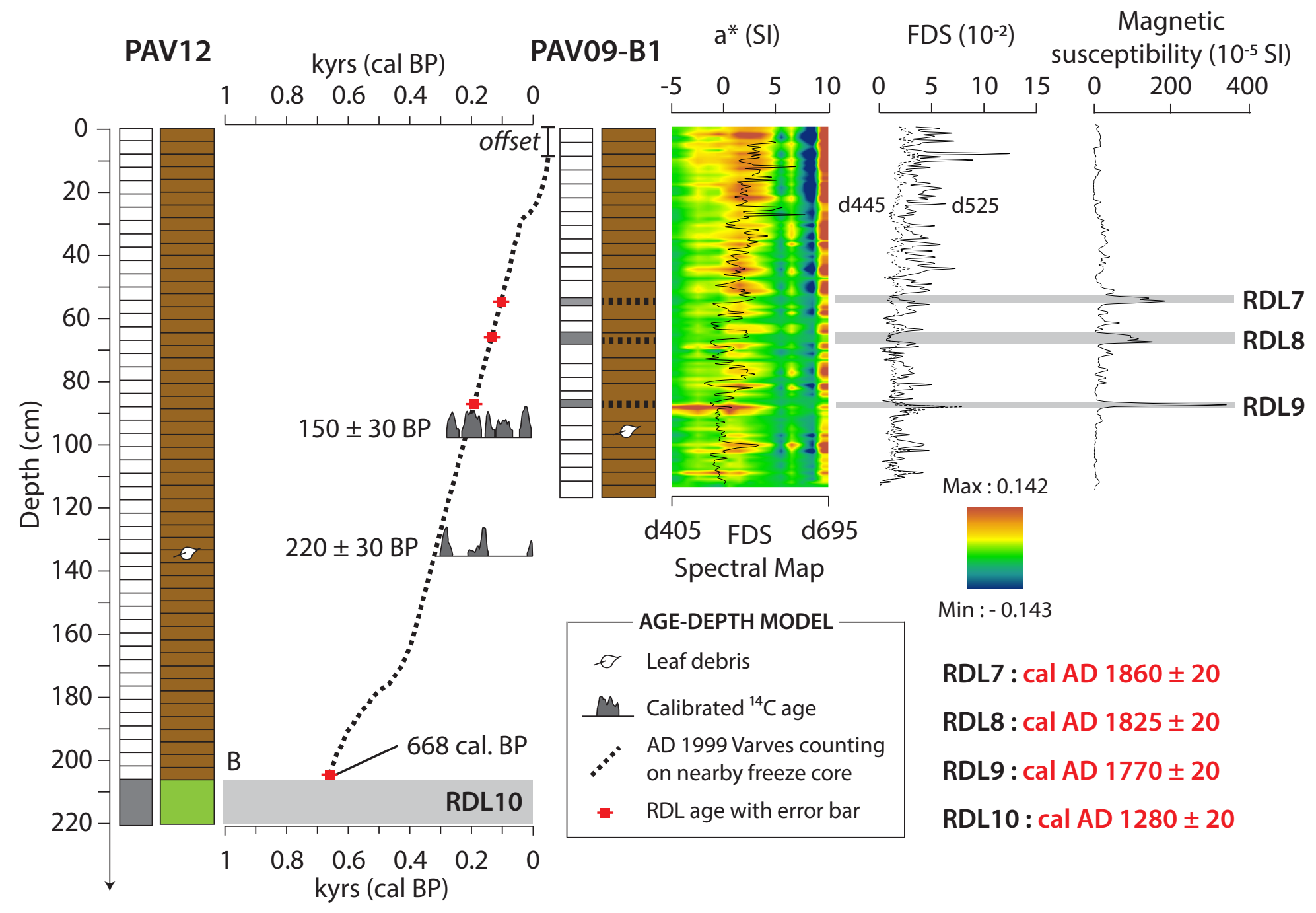




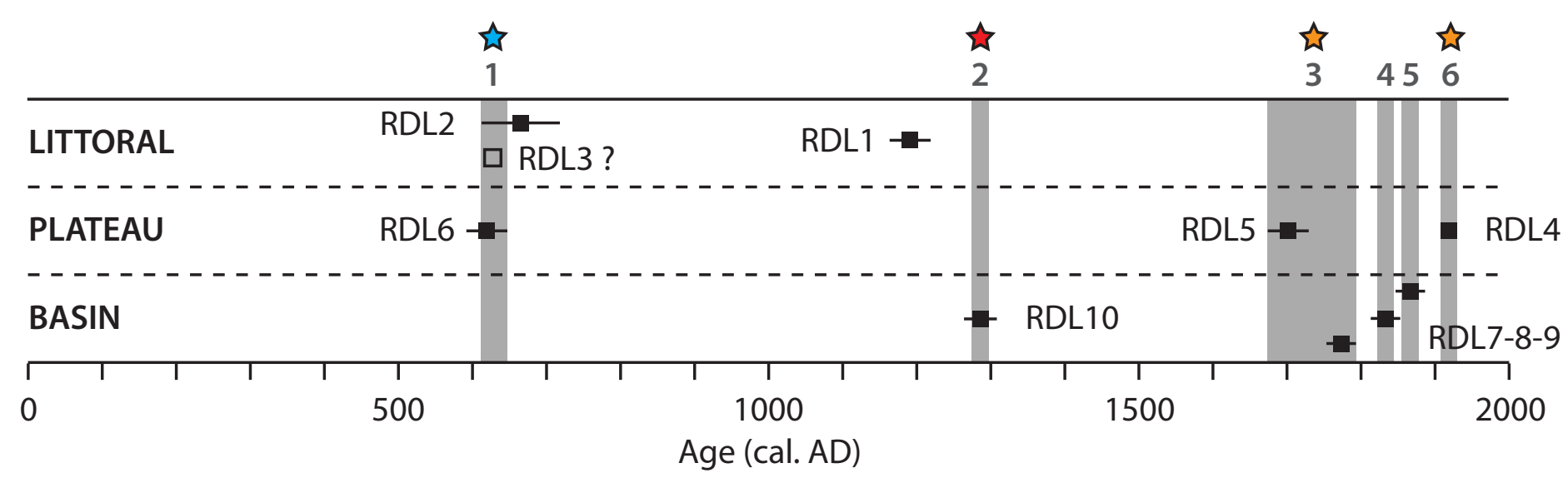

Sedimentary event Slope failure Outburst Simnic eruption 

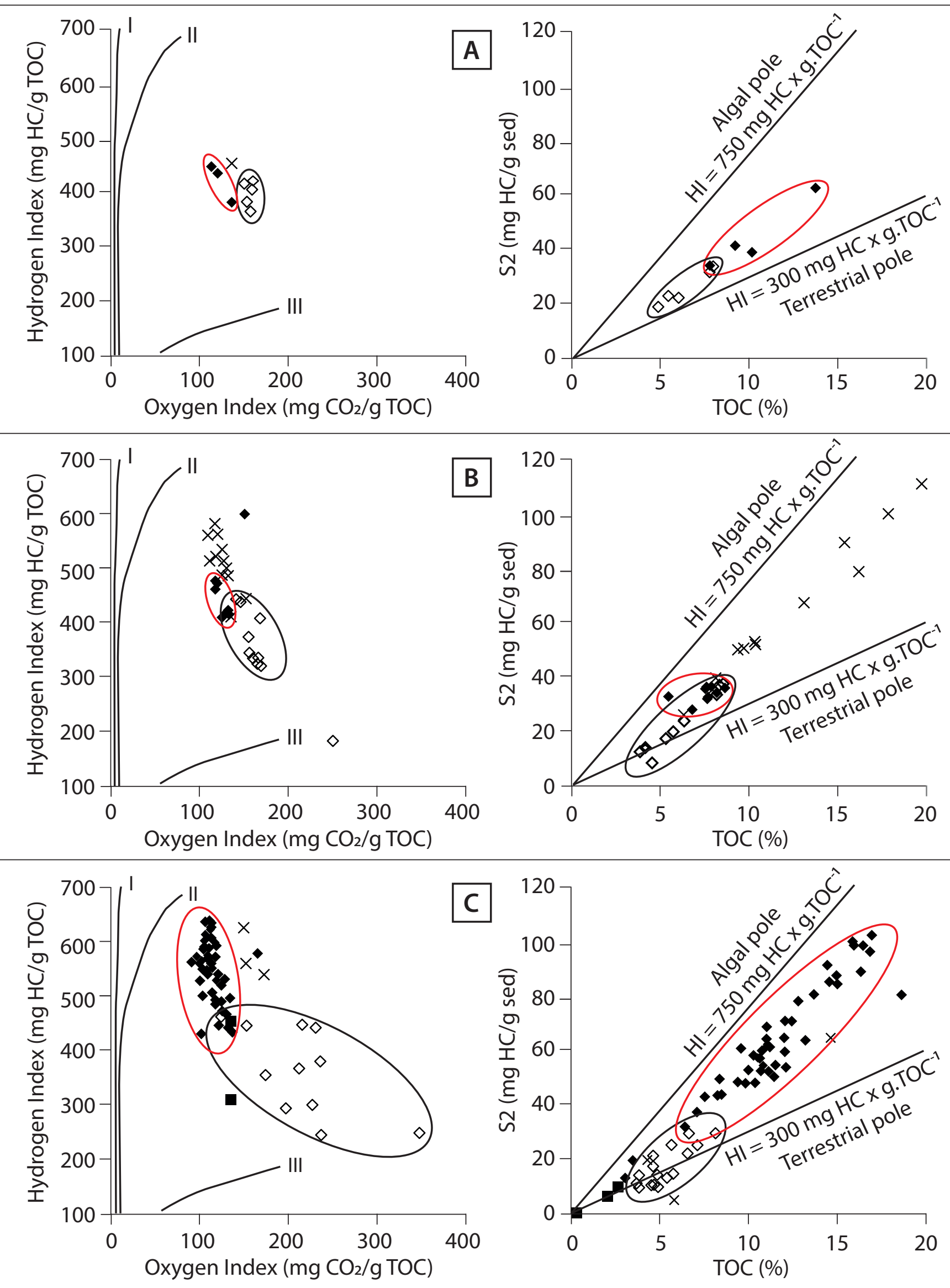

Basal unit

- Lower organic unit

$\times$ RDLs

$\diamond$ Upper organic unit 


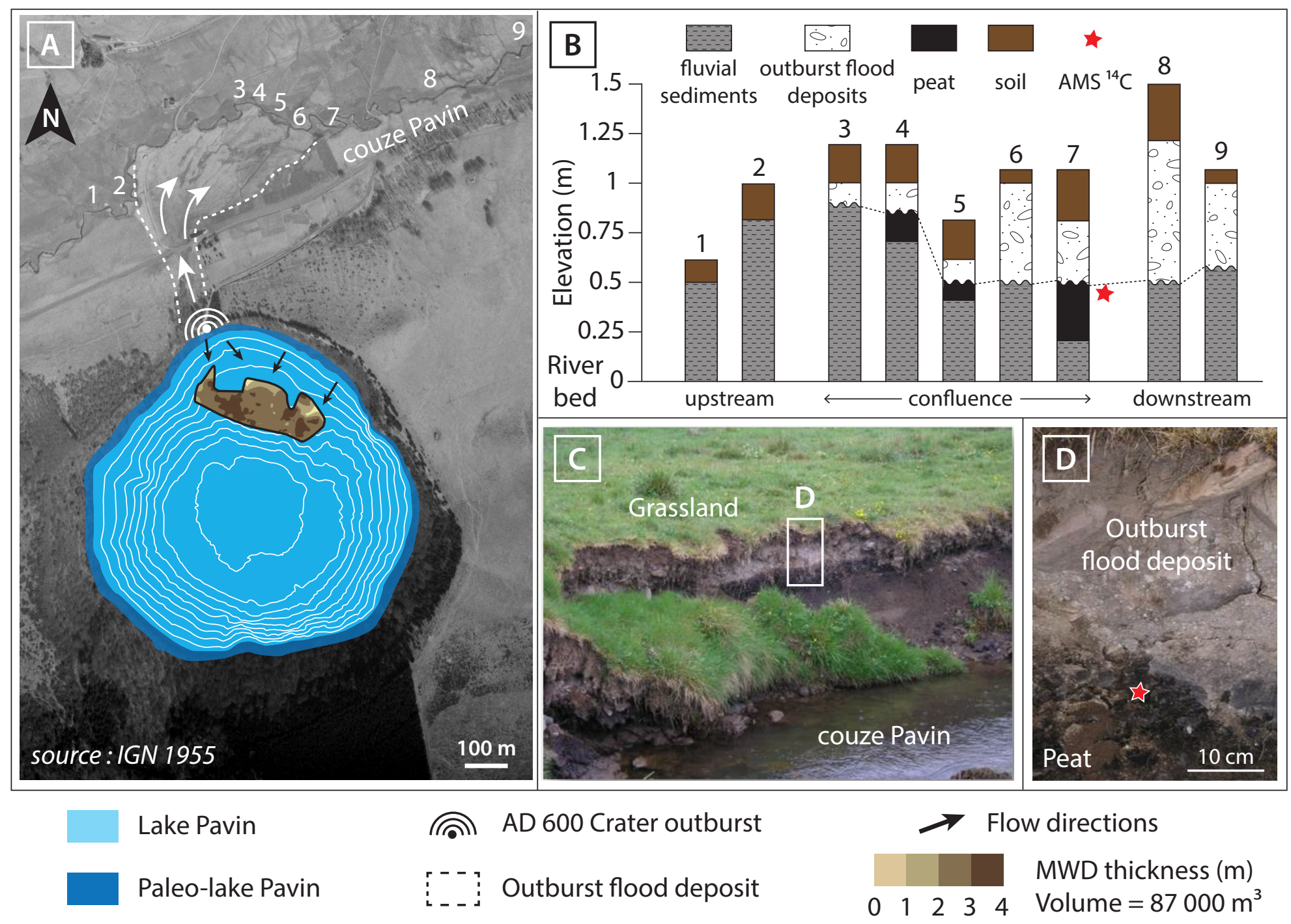




\begin{tabular}{|c|c|c|c|c|c|c|}
\hline Location & Core & $\begin{array}{l}\text { Depth } \\
\text { (cm) }\end{array}$ & $\begin{array}{l}\text { Laboratory } \\
\text { reference }\end{array}$ & Material & $\begin{array}{l}\text { Radiocarbon } \\
\text { age (BP) }\end{array}$ & $\begin{array}{l}\text { Calibration with two } \\
\text { sigma ranges (cal. BP) }\end{array}$ \\
\hline \multirow{6}{*}{ Basin } & PAV09-B1 & 96.5 & Poz-33126 & Leaf & $150 \pm 30$ & Plateau \\
\hline & PAV12 & 137 & Lyon-10961 & Leaf & $220 \pm 30$ & Plateau \\
\hline & PAV12 & 288 & Beta-336272 & Leaf & $2210 \pm 30$ & $2230 \pm 90(1)$ \\
\hline & PAV12 & 645.5 & SacA34984 & Leaf & $1730 \pm 30$ & $1635 \pm 70(1)$ \\
\hline & PAV12 & 827 & Beta-335372 & Leaf & $3400 \pm 30$ & $3645 \pm 70(1)$ \\
\hline & PAV12 & 978.5 & Lyon-10962 & Leaf & $5250 \pm 35$ & $5980 \pm 55(0.63)$ \\
\hline \multirow{4}{*}{ Plateau } & PAV08 & 23 & Poz-31851 & Leaf & $1210 \pm 30$ & $1125 \pm 65(0.87)$ \\
\hline & PAV08 & 71 & Poz-27046 & Leaf & $1290 \pm 35$ & $1235 \pm 60(1)$ \\
\hline & PAV08 & 97 & Poz-27047 & Leaf & $1430 \pm 21$ & $1330 \pm 30(1)$ \\
\hline & PAV08 & $476-479$ & Poz-27052 & Bulk & $6090 \pm 40$ & $6940 \pm 90(0.84)$ \\
\hline \multirow{2}{*}{ Littoral } & PAV09-C5 & 9 & UCIAMS-92406 & Leaf & $855 \pm 15$ & $760 \pm 30(1)$ \\
\hline & PAV09-C5 & 18 & Poz-27052 & Leaf & $1355 \pm 35$ & $1285 \pm 50(0.92)$ \\
\hline \multicolumn{3}{|c|}{ Couze Pavin River } & UCIAMS-92407 & Peat & $1825 \pm 20$ & $1765 \pm 55(1)$ \\
\hline
\end{tabular}

TABLE 1 


\begin{tabular}{|c|c|c|c|c|}
\hline Location & Date & $\begin{array}{c}\text { Lake } \\
\text { drawdown (m) }\end{array}$ & $\begin{array}{l}\text { Volume of water } \\
\text { released }\left(\mathrm{km}^{3}\right)\end{array}$ & $\begin{array}{c}\text { Peak discharge } \\
\left(\times 10^{3} \mathrm{~m}^{3} \cdot \mathrm{s}^{-1}\right)\end{array}$ \\
\hline Lake Pavin, FR & AD 600 & 9 & 0.00396 & 1.5 \\
\hline Lake Toba, ID & Post-75 ka & $>100$ & 150 & - \\
\hline Lake Rotorua, NZ & $28 \mathrm{ka}$ & $>90$ & 10 & - \\
\hline \multirow{2}{*}{ Lake Taupo, NZ } & Post-26.5 ka & 80 & 60 & 350 \\
\hline & Post-1.8 ka & 32 & 20 & 25 \\
\hline \multirow{4}{*}{ Lake Tawarera, NZ } & Post-13.8 ka & $>80$ & 5 & - \\
\hline & Post-8 ka & $>80$ & 4 & - \\
\hline & Syn-0.7 ka & 40 & 1.4 & 50 \\
\hline & AD 1904 & 3.3 & 0.0135 & 0.7 \\
\hline \multirow{2}{*}{$\begin{array}{c}\text { Ruapehu Crater Lake, } \\
\text { NZ }\end{array}$} & AD 1953 & 8 & 0.00180 & 0.35 \\
\hline & AD 2007 & 6 & 0.00140 & 0.53 \\
\hline Lago Ilopango, SV & AD 1880 & 9 & 1.2 & 3 \\
\hline Pinatubo Crater lake, $\mathrm{PH}$ & AD 2002 & 23 & 0.065 & $3-5$ \\
\hline \multirow{2}{*}{ Lake Maughan, $\mathrm{PH}$} & AD 1995 & 10 & 0.033 & - \\
\hline & AD 2002 & 8 & 0.027 & - \\
\hline \multirow{2}{*}{ Okmok, USA } & $0.8 \mathrm{ka}$ & 150 & 5.8 & 1900 \\
\hline & AD 1817 & 8 & - & 2 \\
\hline
\end{tabular}

TABLE 2 